\title{
Scientific Opportunities to Reduce Risk in Groundwater and Soil Remediation
}

$\begin{array}{llll}\text { EM Pierce } & \text { BB Looney } & \text { D Lesmes } & \text { V Adams } \\ \text { MD Freshley } & \text { JM Zachara } & \text { GH Chamberlain } & \text { ME Denham } \\ \text { SS Hubbard } & \text { L Liang } & \text { KL Skubal } & \text { DM Wellman }\end{array}$

August 2009

\section{Pacific Northwest}

NATIONAL LABORATORY

Proudly Operated by Battelle Since 1965 


\title{
DISCLAIMER
}

This report was prepared as an account of work sponsored by an agency of the United States Government. Neither the United States Government nor any agency thereof, nor Battelle Memorial Institute, nor any of their employees, makes any warranty, express or implied, or assumes any legal liability or responsibility for the accuracy, completeness, or usefulness of any information, apparatus, product, or process disclosed, or represents that its use would not infringe privately owned rights. Reference herein to any specific commercial product, process, or service by trade name, trademark, manufacturer, or otherwise does not necessarily constitute or imply its endorsement, recommendation, or favoring by the United States Government or any agency thereof, or Battelle Memorial Institute. The views and opinions of authors expressed herein do not necessarily state or reflect those of the United States Government or any agency thereof.

\author{
PACIFIC NORTHWEST NATIONAL LABORATORY \\ operated by \\ BATTELLE \\ for the \\ UNITED STATES DEPARTMENT OF ENERGY \\ under Contract DE-ACO5-76RL01830
}

Printed in the United States of America
Available to DOE and DOE contractors from the
Office of Scientific and Technical Information,
P.O. Box 62, Oak Ridge, TN 37831-0062;
ph: (865) 576-8401
fax: (865) 5765728
email: reports@adonis.osti.gov

\footnotetext{
Available to the public from the National Technical Information Service, U.S. Department of Commerce, 5285 Port Royal Rd., Springfield, VA 22161 ph: (800) 553-6847 fax: (703) 605-6900

email: orders@nits.fedworld.gov online ordering: http://www.ntis.gov/ordering.htm
} 


\title{
Scientific Opportunities to Reduce Risk in Groundwater and Soil Remediation
}

\author{
EM Pierce ${ }^{1,2}$ \\ BB Looney ${ }^{4}$ \\ D Lesmes ${ }^{6}$ \\ V Adams ${ }^{2}$ \\ MD Freshley ${ }^{1}$ \\ JM Zachara ${ }^{1}$ \\ GH Chamberlain ${ }^{2}$ \\ ME Denham ${ }^{4}$ \\ SS Hubbard ${ }^{3}$ \\ L Liang $^{5}$ \\ KL Skubal ${ }^{2}$ \\ DM Wellman \\ ${ }^{1}$ Pacific Northwest National Laboratory \\ ${ }^{2}$ DOE-EM Office of Groundwater and Soil \\ ${ }^{3}$ Lawrence Berkeley National Laboratory \\ ${ }^{4}$ Savannah River National Laboratory \\ ${ }^{5}$ Oak Ridge National Laboratory \\ ${ }^{6}$ DOE-SC Office of Biological and Environmental Research
}

August 2009

Prepared for

the U.S. Department of Energy

under Contract DE-AC05-76RL01830

Pacific Northwest National Laboratory

Richland, Washington 99352 


\section{Executive Summary}

The U.S. Department of Energy (DOE) Office of Environmental Management (EM) has made considerable progress cleaning up groundwater and soil contamination, but significant challenges remain. The inability to address these challenges often results in inefficient cleanup actions at a number of key sites. Moreover, systematic gaps in the technical foundation supporting environmental decisions have led to ineffective remediation and uncoordinated policies (Congress 2006). An effective applied research program, one that successfully links basic science knowledge to real-world schedules and challenges, is a critical path toward improving the technical foundations of DOE EM.

The objective of this document is to communicate an approach for DOE EM and the Office of Science (SC) to collaborate and establish a technical basis for science and technology investments needed by DOE EM to accelerate and complete groundwater and soil remediation. In this report, we start by examining previous efforts at linking science and DOE EM research with cleanup activities. Many of these efforts were initiated by creating science and technology roadmaps. A recurring feature of successfully implementing these roadmaps into EM applied research efforts and successful cleanup is the focus on integration. Such integration takes many forms, ranging from combining information generated by various scientific disciplines, to providing technical expertise to facilitate successful application of novel technology, to bringing the resources and creativity of many to address the common goal of moving EM cleanup forward. Successful projects identify and focus research efforts on addressing the problems and challenges that are causing "failure" in actual cleanup activities. In this way, basic and applied science resources are used strategically to address the particular unknowns that are barriers to cleanup. The brief descriptions of SC's basic (Environmental Remediation Science Program [ERSP]) and EM's applied (Groundwater and Soil Remediation Program) research programs in subsurface science provide context to the five "crosscutting" themes that have been developed in this strategic planning effort. To address these challenges and opportunities, a tiered systematic approach is proposed that leverages basic science investments with new applied research investments from the DOE Office of Engineering and Technology within the framework of the identified basic science and applied research crosscutting themes. These themes are evident in the initial portfolio of initiatives in the EM groundwater and soil cleanup multi-year program plan (DOE 2008c). As stated in a companion document for tank waste processing (Bredt et al. 2008), in addition to achieving its mission, DOE EM is experiencing a fundamental shift in philosophy from driving to closure, to enabling the long-term needs of DOE and the nation.

EM has developed applied field research sites at Savannah River Site, Oak Ridge Reservation, and Hanford Site to address a wide range of challenges outlined in this document. These applied research sites will also facilitate coordination with the DOE Office of Science (SC) and leverage the developments from the Scientific Focus Areas and Integrated Field Research Challenge sites funded by DOE SC ERSP. The activities at these sites clearly exemplify the EM vision and the linkage of basic science, applied research, and cleanup operations. The applied research projects are structured to transition science into practice and to support achieving site closure-for example, by incorporating attenuation-based remedies for metals and radionuclides. In addition to these applied research projects, the initial EM groundwater and soil remediation program has implemented outreach and technical support activities so that the applied research will be put into action. The proposed tiered approach puts the resulting "science to work" in partnership with federal and state organizations, such as the Environmental Protection Agency 
and the Interstate Technology and Regulatory Council, and through outreach and EM technical assistance programs. 


\section{Acronyms}

ARTDD Applied Research and Technology Development and Deployment

ASCR

Advanced Scientific Computing Research

BJC Bechtel Jacobs Company

CERCLA Comprehensive Environmental Response, Compensation, and Liability Act

CHPRC $\quad \mathrm{CH} 2 \mathrm{M}$ Hill Plateau Remediation Contract

CRESP Consortium for Risk Evaluation with Stakeholder Participation

CWA Clean Water Act

D\&D Deactivation and Decommissioning

DNFSB Defense Nuclear Facilities Safety Board

DOC dissolved organic carbon

DOE U.S. Department of Energy

DOE/ID U.S. Department of Energy-Idaho Operations Office

EFPC East Fork Popular Creek

EM Office of Environmental Management

EMSP Environmental Management Science Program

EPA U.S. Environmental Protection Agency

CESD Climate and Environmental Sciences Division

ERSP Environmental Remediation Sciences Program

FS Feasibility Study

IFRC Integrated Field Research Challenge Site

INL Idaho National Laboratory

ISRM In Situ Redox Manipulation

LBNL Lawrence Berkeley National Laboratory

LFI limited field investigation

LM Legacy Management

MCL maximum contaminant level

MNA monitored natural attenuation

MYPP multi-year program plan

NAS National Academy of Sciences

NPDES National Pollution Discharge Elimination System

NRC National Research Council

OBER Office of Biological and Environmental Research

OE\&T Office of Engineering and Technology 
OREIS Oak Ridge Environmental Information System

ORFRC Oak Ridge Field Research Center

ORIFC Oak Ridge Integrated Field Challenge

ORNL Oak Ridge National Laboratory

ORO Oak Ridge Operations

ORR Oak Ridge Reservation

PCB polychlorinated biphenyl

PCE perchloroethylene

PNNL Pacific Northwest National Laboratory

PI principal investigator

RI Remedial Investigation

RMPE Reduction of Mercury in Plant Effluents

SAMMS self-assembled monolayers on ordered mesoporous supports

SC Office of Science (DOE)

SFA scientific focus area

SLAC Stanford Linear Accelerator Center

SNF Spent Nuclear Fuel

SRNL Savannah River National Laboratory

SRS Savannah River Site

TCE trichloroethylene

TPA Tri-Party Agreement

UEFPC Upper EFPC 


\section{Contents}

Executive Summary .......................................................................................................... iii

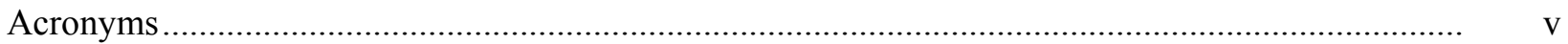

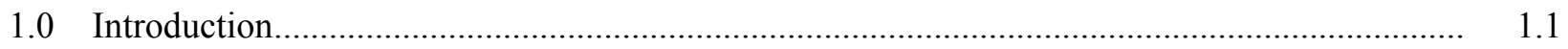

2.0 Groundwater and Soil Contamination and Remediation at DOE EM Sites.............................. 2.1

3.0 DOE Subsurface Science Research: A Historic Perspective of Application to EM Legacy

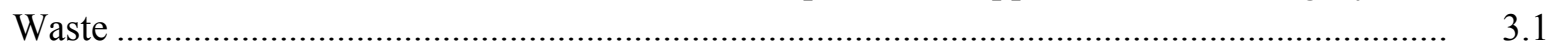

3.1 Subsurface Science Roadmap Efforts ....................................................................... 3.1

3.1.1 Hanford Groundwater/Vadose Zone Roadmap ................................................. 3.2

3.1.2 National Roadmap for Vadose Zone Science and Technology ............................... 3.4

3.1.3 EM Technology Roadmap ............................................................................. 3.5

4.0 Environmental Remediation Sciences Program................................................................... 4.1

5.0 EM Groundwater and Soil Remediation Program ............................................................... 5.1

6.0 Path Forward: An Approach for DOE EM/SC Collaboration to Address DOE EM's Most

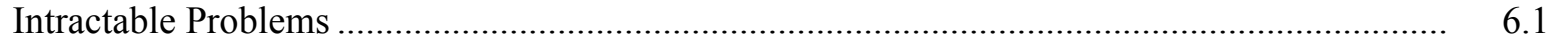

6.1 Oak Ridge Reservation: Oak Ridge Mercury Research Integration Example ................... $\quad 6.5$

6.2 Proposed Strategy to Leverage Basic Science and Applied Research Investments ............ $\quad 6.7$

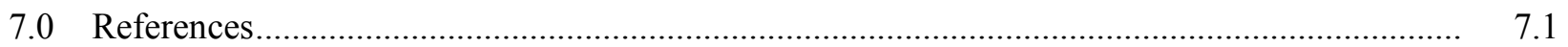

Appendix A: Examples of DOE Groundwater and Soil/ERSP Integration to Address DOE EM's Most Intractable Problems ............................................................................................... A.1

A.1 Savannah River Site: F-Area Research Integration Example......................................... A.1

A.2 Oak Ridge Reservation: Oak Ridge Uranium Research Integration Example.................... A.4

A.3 Hanford Site: 100 Area Research Integration Example ................................................. A.6

A.4 Hanford Site: 300 Area Research Integration Example ................................................... A.9

A.5 Hanford Site: BC Cribs and Trenches Research Integration Example............................... A.12

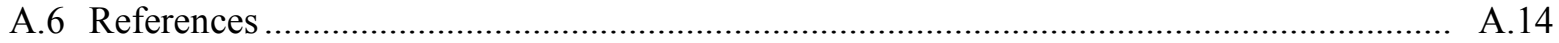




\section{Figures}

3.1. Hanford Groundwater/Vadose Zone Integration Project Roadmap: Structure, Major Accomplishments, and Remaining Gaps

4.1. DOE's Remediation Challenges Occur in the Field Where Highly Interactive Natural Processes, Which Occur over a Broad Range of Scales, Control the Fate and Transport of Contaminants

4.2. Hierarchical Structure and Coordination of the ERSP Research Program

5.1. DOE EM Engineering and Technology Program Integration.

5.2. DOE's The Soils and Groundwater Remediation Program Is Designed to Solve Problems and Respond to Needs at the Following DOE Sites: Hanford, DOE/ID, ORR, SRS, Paducah, and Portsmouth

6.1. Interface Between Basic Science (SC) and Applied Research (EM) in Subsurface Science

6.2. Oak Ridge Y-12 EM and ERSP Linkages for Mercury

A.1. Example of F-Area Seepage Basin Remediation.

A.2. SRS EM F-Area EM and ERSP Linkages

A.3. Oak Ridge Y-12 Complex EM and ERSP Linkages for Uranium.

A.4. Map of Cr Concentration in Groundwater at Hanford 100-H and 100-D Areas, Both Located Near the Columbia River

A.5. Hanford 100 Area EM and ERSP Linkages ....

A.6. Hanford 300 Area EM and CESD Linkages.

A.7. Hanford BC Cribs and Trenches EM and CESD Linkages 


\subsection{Introduction}

The U.S. Department of Energy (DOE) Office of Environmental Management (EM) is responsible for risk reduction and cleanup of the environmental legacy of the Nation's nuclear weapons production and nuclear energy research. The Cold War legacy has resulted in more than 134 distinct geographic sites in 31 states and a U.S. territory that are contaminated by a diverse mixture of contaminants present in a wide variety of subsurface environments. The sheer volume of contaminated groundwater, soil, and sediments that require remediation makes this cleanup program one of the largest, most diverse, and most complex in the world.

Over the last decade, DOE EM has made significant progress shifting from waste management to a mission-completion philosophy, based on reducing risk and environmental liability. Through its cleanup approach, EM is remediating groundwater and soil contaminated with radioactive and hazardous chemicals and metals, thereby reducing the risks of the environmental contamination for future generations. The goal of DOE EM is to continue to reduce the environmental liability associated with legacy waste.

The Office of Engineering and Technology (OE\&T) is the DOE EM organization tasked with providing technical assistance to sites to reduce project risk and uncertainty. OE\&T has a long tradition of supporting the development of remediation solutions for subsurface contamination by supporting applied research and technology development and providing technical and engineering assistance to site managers across the DOE complex. This long history of supporting sites is evident through programs that have been developed and administered through this office, such as 1) DOE EM Subsurface Contaminant Focus Area, 2) DOE Environmental Management Science Program (co-administered with DOE Office of Science), and 3) the current Groundwater and Soil Remediation Program.

The objective of this document is to communicate an approach for DOE EM and SC to collaborate and establish a technical basis for science and technology investments needed by DOE EM to accelerate and complete groundwater and soil remediation. This document is intended to foster a dialog on how basic science and applied research can assist DOE in executing its cleanup and environmental management mission.

The information contained in this report is separated into five sections to effectively communicate and address the stated objective. Section 2.0 of the report discusses the estimated life-cycle cost for groundwater and soil remediation, past accomplishments that have occurred as a result of EM's science and technology investments, and a brief description of the challenges that remain at several of the major DOE sites. Section 3.0 provides a historic perspective of the application of subsurface science research to DOE EM legacy waste problems. This section provides a links between the needs identified in the Groundwater/Vadose Zone Roadmap and National Roadmap for Vadose Zone Science and Technology to the current EM Technology Roadmap. Brief descriptions of the Environmental Remediation Science Program (the DOE Office of Science's [SC's] basic science program) and the Groundwater and Soil Remediation Program (DOE EM's applied research program) are provided in Sections 4.0 and 5.0, respectively. These descriptions communicate the goal and motivation of each program and highlight their differences. Finally, Section 6.0 provides an approach for DOE EM and SC to coordinate and 
identifies the basic science and applied research areas that are needed to address DOE EM's most intractable problems. 


\subsection{Groundwater and Soil Contamination and Remediation at DOE EM Sites}

The DOE complex represents, arguably, one of the largest, most complex, and formidable subsurface environmental restoration challenges in the world. One important component of DOE's environmental management mission is the cleanup of groundwater, soils, and sediments in highly diverse environments contaminated with radionuclides, metals, and organics, in some cases present as complex mixtures. These resources were contaminated through a variety of pathways, including intentional disposal into the ground through injection wells, disposal pits, and settling ponds as well as from accidental spills and leaks from storage tanks and waste transfer lines. In some cases, minimal historical information exists of the magnitude, timing, and content of contaminant releases to the environment. Additionally, the broad range of climatic, ecologic, and geohydrologic conditions that exist across the DOE complex makes it difficult to predict the location, transport, and fate of these contaminants in the environment. A combination of limited documentation and the difficulty in predicting the fate and transport after releases make estimates of the magnitude of the problem and cleanup costs vary considerably. In 1997, DOE estimated the total amount of contaminated groundwater and soil to be $1800 \times 10^{6} \mathrm{~m}^{3}$ and $75.0 \times 10^{6} \mathrm{~m}^{3}$, respectively (DOE 1997). The financial obligation required to remediate this volume of contaminated environment is estimated to cost more than $\$ 15$ billion (approximately 10 percent of the projected 1998 life-cycle cost of $\$ 147.3$ billion) (DOE 1998a). The life-cycle cost was revised in 2000 and again in 2002, estimated to be between $\$ 168$ and $\$ 212$ billion (includes the $\$ 17$ billion incurred between FY1997 and FY1999) and $\$ 220$ billion, respectively (DOE 2000a; Abraham 2002). Based on the projected 2002 life-cycle cost estimate of $\$ 220$ billion, the cost to complete environmental restoration with the existing baseline technologies would be approximately $\$ 22$ billion over a 70-year period (estimate assumes remediation is 10 percent of the projected life-cycle cost).

Since its inception, DOE EM has cleaned up a number of key sites across the country, including the Fernald Site near Cincinnati, OH, and the Rocky Flats Site near Denver, Colorado, each of which has been transformed into a nature preserve, the latter being a National Wildlife Refuge. The Fernald Site was the location of a former uranium processing facility located 18 miles northwest of Cincinnati, $\mathrm{OH}$, that produced uranium metal for use throughout the nuclear weapons complex during the Cold War era. DOE EM and its contractors began restoration of the Fernald Site in 1991 after nearly four decades of operation. The Fernald Closure Project was completed in October 2006, 12 years sooner and for almost $\$ 8$ billion less than original estimates. Similar to Fernald, the Rocky Flats Site was the location of a former manufacturing facility for nuclear weapons components located 16 miles northwest of Denver, Colorado. For nearly five decades, the Rocky Flats Site processed plutonium for reuse, manufactured defense-related components from depleted uranium, and produced plutonium "triggers" for the Nation's nuclear weapons stockpile. DOE EM and its contractors began restoration of the site in 1995 . Work was completed in October 2005, 50 years faster and $\$ 30$ billion less than original estimates. The estimated total cost for closing Fernald and Rocky Flats was \$2.9 billion and \$10 billion (includes the long-term stewardship cost), respectively. The Fernald and Rocky Flats sites were transferred to the Office of Legacy Management in October 2006 and 2007, respectively.

Closure of Fernald and Rocky Flats was a direct result of the EM Closure Site Initiative, which resulted in saving the U.S. taxpayers approximately $\$ 40$ billion. Although EM has been successful in closing and treating many of the subsurface groundwater and soil issues at several other sites within the 
complex, the more intractable issues remain, and finding solutions to these problems will be the challenge facing DOE for the next decade. To address the remaining first-of-a-kind challenges at larger EM sites (i.e., Idaho National Laboratory [INL], Hanford Site, Savannah River Site [SRS], and Oak Ridge Reservation [ORR]), EM has placed a renewed emphasis on the implementation of science-, engineering-, and technology-based solutions to reduce the technical risk and uncertainty in project execution. Many of the challenges that affect the larger sites also plague closure efforts at smaller sites (Paducah, Portsmouth, West Valley, etc.). As is evident by the Fernald and Rocky Flats Cleanup Projects, implementing science-, engineering-, and technology-based solutions has traditionally lowered life-cycle cost by accelerating the cleanup schedule, improving worker safety, reducing environmental risk, and offering better, safer, and cheaper alternatives to the baseline technologies. For example, at Mound, implementing a science and engineering technical assistance program at a cost of \$2.7 million resulted in a \$30 million cost savings in the form of more economical cleanup approaches, regulatory acceptance of new innovative approaches, and acceleration of the cleanup efforts. Technical assistance is an approach that engages subject matter experts (typically experienced scientists and engineers) at various stages of the remedial decision-making process. Similar cost savings have also occurred during cleanup activities at Ashtabula, SRS, and INL.

The intractable subsurface problems that remain to be dealt with are clearly some of the most complex ever encountered by the technical community, especially at the larger sites such as Savannah River, ORR, and Hanford. The SRS, located in south-central South Carolina, has extensive groundwater plume containing ${ }^{90} \mathrm{Sr}$, uranium isotopes, ${ }^{129} \mathrm{I}$, tritium, and nitrate at concentrations that exceed the maximum contaminant level (MCL). Additionally, the leakage of low-level radioactive waste, mixed waste, and intermediate-level radioactive waste disposed of in burial grounds, located in the central part of SRS, has resulted in groundwater plumes that contain various organic solvents, heavy metals, and radionuclides. The ORR, located in eastern Tennessee, has extensive contamination of the environment, including soils, groundwater, surface water, and biota with mercury. Additionally, significant amounts of other contaminants were released into the environment, including radionuclides (various isotopes of $\mathrm{U}$, ${ }^{90} \mathrm{Sr},{ }^{239} \mathrm{Pu},{ }^{60} \mathrm{Co},{ }^{99} \mathrm{Tc},{ }^{232} \mathrm{Th},{ }^{137} \mathrm{Cs}$, etc. $)$, heavy metals $(\mathrm{Pb}, \mathrm{Cr}, \mathrm{Cd}, \mathrm{Ni}$, and $\mathrm{Co})$, nitrate, various inorganic compounds, and organics, such as polychlorinated biphenyls (PCBs), trichloroethylene (TCE), perchloroethylene (PCE), and pesticides. These releases have created large groundwater plumes that discharge to nearby creeks and water bodies. The Hanford Site, located in southeastern Washington State, has subsurface contamination concentrated in two locations: the Columbia River Corridor and the Central Plateau. These areas include soils and groundwater contaminated with radionuclides (various isotopes of $\mathrm{U},{ }^{90} \mathrm{Sr},{ }^{99} \mathrm{Tc},{ }^{129} \mathrm{I}$, etc.), nitrate, carbon tetrachloride, inorganic compounds, and organics, such as PCBs and TCE. In addition the Central Plateau is characterized with a deep vadose zone containing numerous contaminant plumes. 


\subsection{DOE Subsurface Science Research: A Historic Perspective of Application to EM Legacy Waste}

For much of the twentieth century, subsurface scientists, specifically hydrologists, were focused on the use of groundwater as a dependable water supply (Freeze and Cherry 1979). With the exception of scientists in the agriculture sector, there was little interest in vadose zone transport. As a result, much of the early subsurface science at DOE sites addressed the hydrologic processes that affected groundwater movement and contaminant transport. During this early stage of the cleanup program, EM realized the need to understand processes that affect contaminant migration in both the groundwater and vadose zone environments. EM also recognized that advances in scientific and engineering knowledge were required to improve cleanup effectiveness and address many of these "first of a kind" challenges. Therefore, DOE developed a subsurface science program in the mid-1990s to engage the scientific and engineering community in the cleanup efforts and to identify the key science and technology issues that, if addressed, would improve the success of the cleanup mission. A number of the key knowledge gaps that impeded advances in subsurface cleanup were identified in two roadmaps: the Hanford Groundwater/Vadose Zone Roadmap and the Vadose Zone Roadmap. An overview of these documents and the recently published Environmental Management Technology Roadmap is provided in the following section. In addition to the roadmaps and their associated research programs, a discussion of the previous subsurface science portion of the Environmental Management Science Program (EMSP) as well as a description of DOE Office of Science's (SC's) current Environmental Remediation Science Program research portfolio is also provided.

\subsection{Subsurface Science Roadmap Efforts}

Over the past decade, DOE EM has used roadmaps and other formal plans to describe science and technology gaps and work needed to fill those gaps. The first roadmap developed by DOE EM was created for the Hanford Site by the Groundwater/Vadose Zone Integration Project (Integration Project) to focus scientific research. Projects were funded by DOE EM to assist with resolution of key issues. The roadmap developed in 1998 (DOE 1998b) was used to guide both a site-directed science and technology project and a call for proposals for the Environmental Management Science Program. The second effort resulted in "A National Roadmap for Vadose Zone Science and Technology" (DOE 2001). This effort was focused on defining activities that would result in understanding, monitoring, and predicting contaminant fate and transport in the unsaturated zone. Both of the previous roadmap efforts were used by DOE EM to generate the "Engineering and Technology Roadmap: Reducing Technical Risk and Uncertainty in the EM Program" (DOE 2008a). The technical elements and major accomplishments from the Groundwater/Vadose Zone Integration Project and remaining science gaps that were identified and used in the development of the Engineering and Technology Roadmap are highlighted in Figure 3.1. This document was prepared to guide the work of the DOE EM Engineering and Technology Program, which was directed to "prepare an EM technology roadmap that identifies technology gaps that exist in the current program, and a strategy with funding proposals to address them." 


\section{HANFORD SITE GROUNDWATER/VADOSE ZONE ROADMAP}

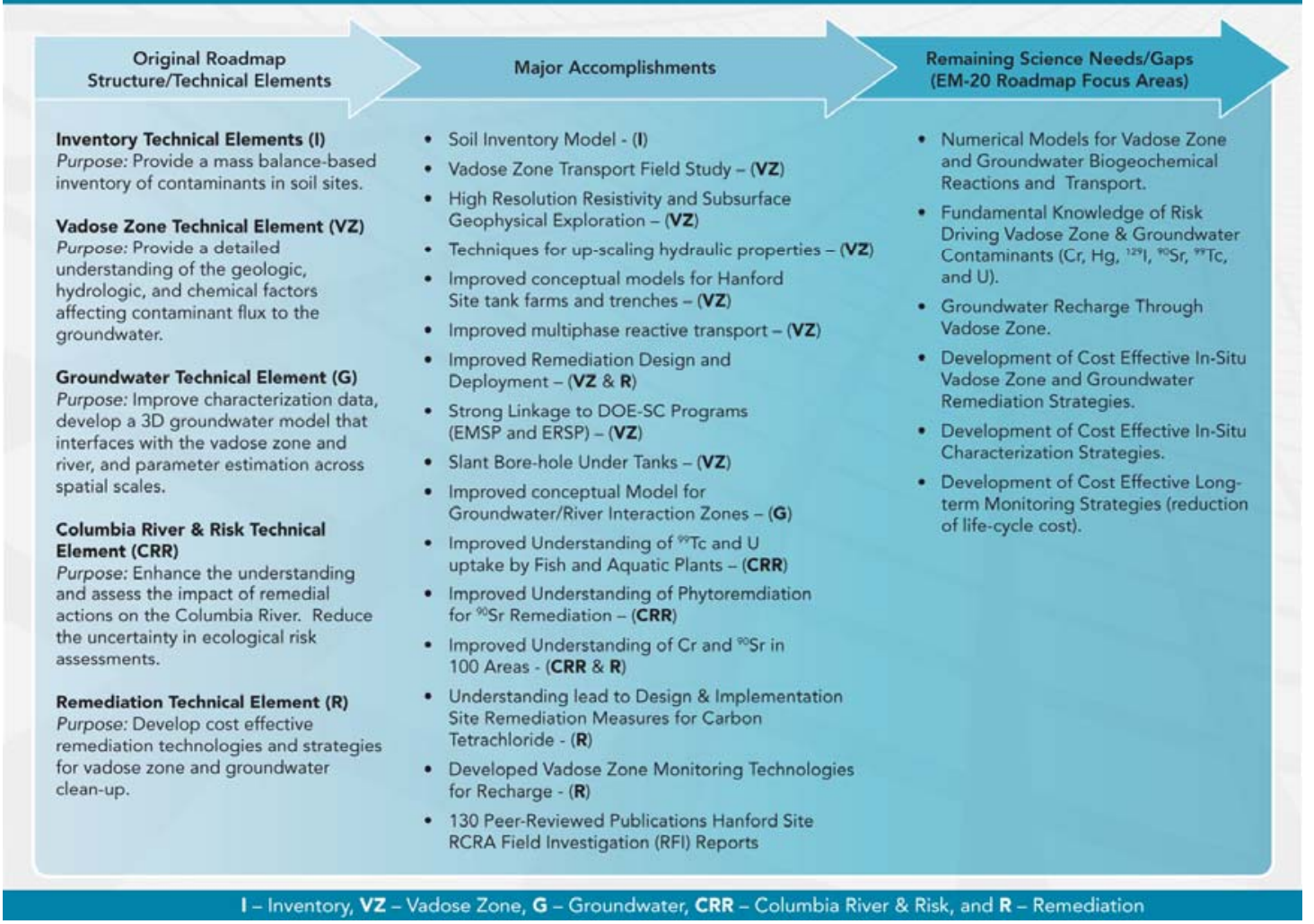

Figure 3.1. Hanford Groundwater/Vadose Zone Integration Project Roadmap: Structure, Major Accomplishments, and Remaining Gaps

\subsubsection{Hanford Groundwater/Vadose Zone Roadmap}

The Integration Project roadmap was used to identify science and technology needs and to define activities to fill the gaps. The roadmap was the primary guide for planning science and technology research needed to address subsurface problems at the Hanford Site and to develop scientific understanding, information, and models needed to support site milestones. The scheduling of these activities in the roadmap was coordinated with site milestones and decision points so that required new knowledge and information was available in time to be used. The Integration Project's science and technology roadmap was developed during FY 1998 to 1999, with review and evaluation by DOE and key Hanford regulators and stakeholders. It was published as Rev. 0 in June 1999 (DOE 1998b). This roadmap was updated twice (DOE 2000b; Freshley et al. 2002).

Rev. 0 of the Integration Project science and technology roadmap was used to influence a call for proposals issued by the DOE EMSP that was focused on vadose zone science issues. Additionally, the Integration Project provided a science plan that identified key scientific issues associated with the longterm migration behavior of high-level waste residuals in the vadose zone. As a result of this coordination, DOE received proposals in response to the call that were both relevant to and focused on specific Hanford Site scientific issues. The EMSP awarded 31 new grants from this call ( $\$ 25 \mathrm{M}$ in work scope over 3 years) directed at vadose zone problems. The scope of the research portfolio addressed, among other 
things, hydrophysical transport processes of high-level waste solutions in heterogeneous vadose zone sediments; geochemical reaction processes of high-level waste solutions and entrained contaminants in vadose zone sediments; geologic controls on water/waste migration in the vadose zone; and geophysical methods for in situ characterization.

When the EMSP projects were selected, DOE also provided funding to the Integration Project to facilitate interaction with the principal investigators and to incorporate their results into meaningful, impactful activities at the Hanford Site (EMSP Linkage Project). DOE instructed the Integration Project to influence and guide, but not to direct, the vadose zone EMSP projects. The Integration Project established and maintained linkages with the EMSP investigators through a series of three focused workshops that paired them with Hanford Site remediation contractors. Considerable mutual understanding and collaboration developed between these parties over the 3-year period with the important result that many of the EMSP research results and findings were applicable to issues resolution and technology needs at the site. In addition to hosting the workshops, the Integration Project provided contaminated and uncontaminated sediment samples to EMSP investigators and facilitated access to the Hanford Site to conduct research. Samples were carefully selected by Integration Project personnel and tailored to the scope/hypotheses of the requesting EMSP project so that the results obtained with them would have maximal potential scientific and site benefit. EMSP principal investigators also participated directly in several field-transport experiments performed at the Integration Project's Vadose Zone Test Facility. In these studies, dilute and saline fluids were injected into the vadose zone to test hypotheses for geologic controls on unsaturated fluid flow. Moisture and tracer plumes were characterized and tracked using different subsurface geophysical methods that are now in use at the Hanford Site for subsurface characterization and monitoring.

The following benefits were realized from the Integration Roadmap and EMSP projects:

- Development of new models that have improved Hanford's ability to describe past ${ }^{137} \mathrm{Cs}^{+}$and $\mathrm{CrO}_{4}{ }^{2-}$ migration events in the vadose zone beneath leaked single-shell tanks and to predict future transport as required for remedial assessment.

- Development of new conceptual models through experimentation that describe the complex geochemical and hydrologic behavior of high-level waste solutions in the vadose zone. The effects of high salt and caustic are now sufficiently understood to speculate on migration behavior of hot, dense, high-level waste supernatant in the Hanford vadose zone and to develop improved reaction/transport models.

- Performance of field experiments at the Hanford Site demonstrating that subtle changes in sediment texture and repetitive, centimeter-scale silt lenses can induce lateral spreading of moisture plumes and contaminants in the vadose zone. These observations have provided a conceptual framework to interpret the complex contaminant distribution patterns noted in the tank farms as well as an impetus to upgrade vadose zone transport models to incorporate this key effect.

- Establishment of a modeling framework for capturing the effects of fine-scale layering and moisturedependent anisotropy. This framework has been deployed to evaluate water flow and ${ }^{99} \mathrm{Tc}$ transport in the vadose zone at the BC Cribs. Models are being used to guide site characterization and wastesite remediation.

- Characterization of one of the largest, single-point releases of uranium at Hanford that has been immobilized approximately $30 \mathrm{~m}$ from a high-level waste tank. These wastes are immobilized by 
precipitation of uranyl-silicates in intergrain fractures of feldspar-containing lithic fragments. The uranium is immobile but has a finite solubility, and its contribution to a groundwater plume underlying the site is being investigated.

- Update of the conceptual model for uranium geochemistry in the vadose zone and the unconsolidated aquifer in the 300 Area. Ongoing investigations in this area are being used to provide input to the design of a remediation approach.

The details of these general findings were incorporated directly into the Field Investigation Reports for the S-SX Tank Farm (S-SX FIR), the B-BX-BY Tank Farm (B-BX-BY FIR), and the T-TX-TY Tank Farm (T-TX-TY FIR), Tri-Party Agreement (TPA) mandated milestones dealing with tank farm corrective actions. In addition, input has been provided to regulatory documents supporting the 300-FF-5 Operable Unit record of decision.

\subsubsection{National Roadmap for Vadose Zone Science and Technology}

During the same timeframe as the development of the Integration Project roadmap, DOE undertook a major review of the state of the art associated with the vadose zone and published a two-volume compendium (Looney and Falta 2000). This publication describes the state of practice and science in vadose zone characterization, monitoring, and modeling as well as technologies for remediation and waste isolation as they existed at that time. The document also included a set of recommendations for filling gaps in knowledge of vadose zone properties and technologies, which provided the basis for the national roadmap for vadose zone characterization, monitoring, and modeling led by INL with broad participation across the communities of practice (DOE 2001).

The National Roadmap for Vadose Zone Science and Technology (Vadose Zone Roadmap) was developed with guidance from an executive committee and work groups that met to define the vadose zone research needs and priorities in March 2000. The work groups were composed of 62 representatives from DOE, its national laboratories, other US government agencies, universities, and industries familiar with end-user needs and vadose zone issues.

A summary of deficiencies and capability gaps within vadose zone characterization, monitoring, and modeling in the DOE complex was prepared as a result of this roadmap effort. This summary provided a national perspective on vadose zone contamination as a threat to groundwater resources.

The Vadose Zone Roadmap focused on research to improve predictions of fate and transport of contaminants in the vadose zone and reduce uncertainty in decisions made by site managers and regulators. The roadmap describes research and application activities and their supporting capabilities and infrastructure, and it outlines an integrated cross-disciplinary approach to accomplish the stated objectives. The roadmap identifies activities to investigate physical, chemical, and biological aspects of vadose zone flow and transport, and the properties and processes needed to measure, monitor, and model vadose zone systems. In the roadmap, near-, mid-, and long-term time horizons were defined. Near-term activities were those that could be completed in about 4 years, the mid-term horizon was approximately a decade, and the long-term horizon was on the order of two to three decades.

The activities defined in the Vadose Zone Roadmap were not funded directly. Some aspects of the roadmap are being addressed through funding at each of the DOE sites. Other aspects are included in 
research funded through the DOE SC Environmental Remediation Sciences Program (ERSP) and by other federal agencies.

\subsubsection{EM Technology Roadmap}

In FY 2007, Congress directed DOE to "prepare an EM technology roadmap that identifies technology gaps that exist in the current program, and a strategy with funding proposals to address them." EM OE\&T developed a roadmap (DOE 2008a) that describes current technology risks for waste processing, decontamination and decommissioning, and groundwater and soil, and the strategies to address those risks. The overall objective of the OE\&T Program is to reduce technical risk and uncertainty in the DOE EM cleanup program. The risk will be reduced by developing technical solutions where none exist, improving solutions that enhance safety and operating efficiency, or adopting technical alternatives that reduce programmatic risks (cost, schedule, or effectiveness). The OE\&T roadmap identifies the engineering and technical risks the DOE EM program faces over the next 10 years, the strategies DOE EM will use to minimize these risks, and the planned outcomes of implementing those strategies. The specifics of the OE\&T Roadmap are discussed later in this document in Section 5.0. 


\subsection{Environmental Remediation Sciences Program}

The need to develop solutions for DOE's intractable environmental remediation problems drives the use-inspired basic science agenda of ERSP. There is currently inadequate understanding of the key physical, chemical, and biological processes that control contaminant fate and transport in realistically complex environments (e.g., vadose zone, saturated zone, and riparian zones). A bottom-up scientific approach, which has traditionally been used by basic science programs, cannot capture the emergent properties of complex systems that often dominate the overall system response. Similarly, a top-down, linear engineering approach, which has traditionally been used by applied research and technology programs, cannot account for the inherent complexity of real earth systems, which leads to ineffective approaches to site characterization, modeling, and management/stewardship. A holistic understanding of contaminant transport in realistically complex environments requires a multi-scale and interdisciplinary approach (Figure 4.1), using iterative experimentation and modeling, to identify and understand the key processes and interactions that control the overall system response. This complex system science approach, which leads to the development of predictive models of contaminant fate and transport, is scientifically not well established.

The mission of the ERSP is to advance our understanding of the fundamental physical, chemical, and biological processes that control contaminant behavior in the environment in ways that help solve DOE's intractable problems in environmental remediation and stewardship.

ERSP advances fundamental science to understand, predict, and mitigate the impacts of environmental contamination from past nuclear weapons production and provide a scientific basis for the long-term stewardship of nuclear waste disposal. The program supports an integrated portfolio of research ranging from molecular to field scales with emphasis on the use of advanced computer models and interdisciplinary, iterative experimentation to understand and predict contaminant transport in complex subsurface environments. The ERSP funds basic research to investigate the key processes affecting the mobility of subsurface contaminants of greatest concern at DOE sites. These contaminants include radionuclides (e.g., $\mathrm{U},{ }^{99} \mathrm{Tc},{ }^{90} \mathrm{Sr}, \mathrm{Pu},{ }^{137} \mathrm{Cs},{ }^{129} \mathrm{I}$, and ${ }^{237} \mathrm{~Np}$ ) and non-radioactive metals (e.g., $\mathrm{Hg}$ and $\mathrm{Cr}(\mathrm{VI})$ ). The ERSP does not fund research on the fate and transport of organic contaminants, which are risk factors at many DOE sites, but the basic science questions regarding the degradation pathways and the eventual fate of organic contaminants in the environment are much better understood than are the processes controlling the fate of radionuclide and heavy metal contaminants in the environment. As described in the following section, the EM Groundwater and Soil Remediation Program supports an applied research program on the fate and transport of organic contaminants at DOE sites, which is informed by aspects of the ERSP basic research program on subsurface characterization and modeling. 


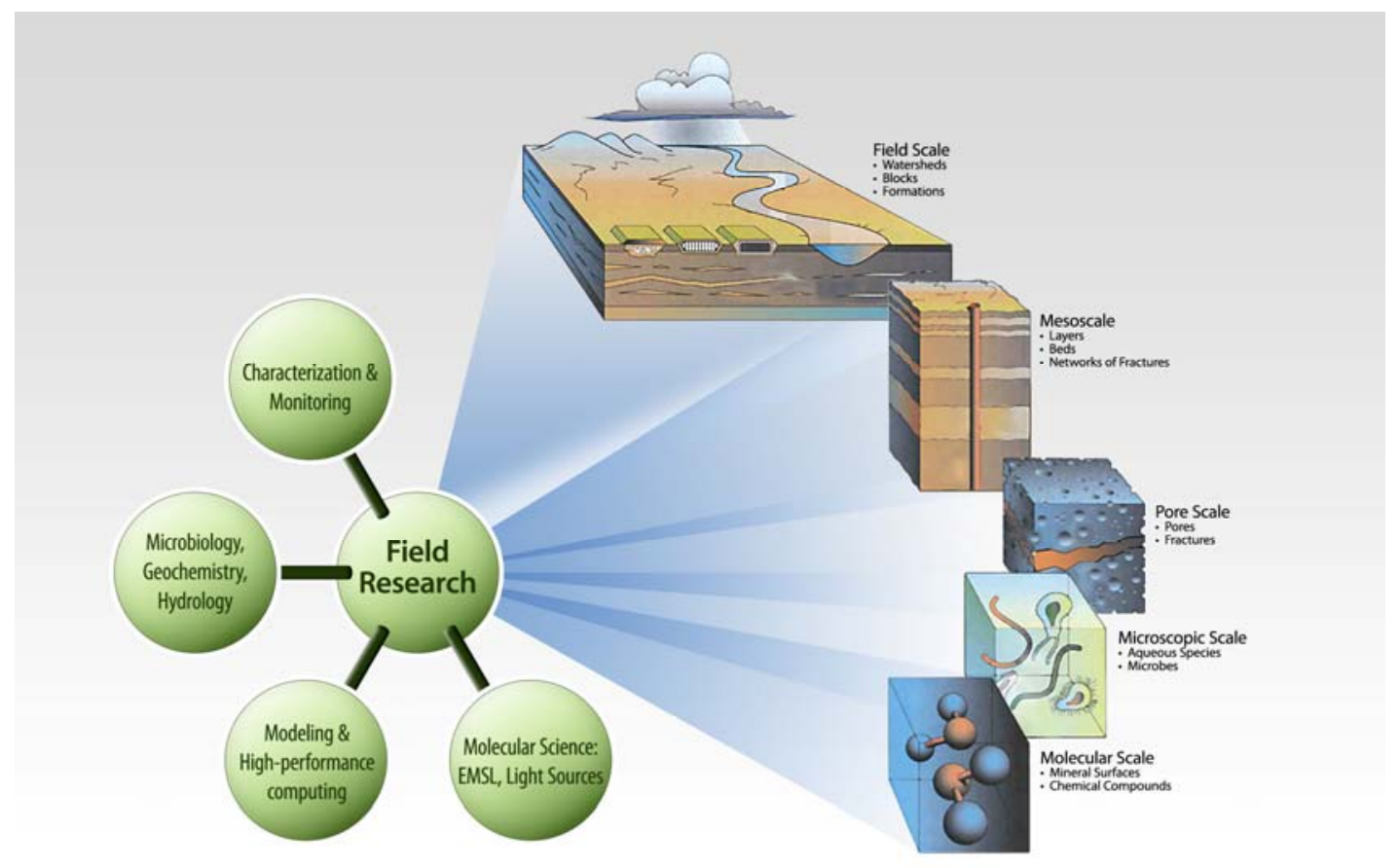

Figure 4.1. DOE's Remediation Challenges Occur in the Field Where Highly Interactive Natural Processes, Which Occur over a Broad Range of Scales, Control the Fate and Transport of Contaminants

To accomplish our mission, ERSP supports a diverse portfolio of coordinated research projects ranging from molecular-scale science to field-scale investigations. Figure 4.2 illustrates the hierarchical structure of the ERSP research program, which consists of three Integrated Field Research Challenge Sites (IFRCs); six national laboratory-led Scientific Focus Areas (SFAs); and a broad array of universityled research projects that are funded through ERSP's annual solicitation.

In FY 2007, ERSP initiated three large interdisciplinary field-scale research projects, funded at $\$ 3$ million/yr for 5 years for a total investment of $\$ 45$ million. The IFRCs are addressing the following basic science questions:

- The Old Rifle IFRC, which is located at an old uranium mill tailings site in Rifle, Colorado, is focused on understanding the microbial and geochemical factors controlling uranium movement in the subsurface. These field studies are being used to guide the development of predictive and mechanistic models of the catalytic role of microbes in the transport and transformation of uranium in subsurface environments.

- The Oak Ridge IFRC, which is located at the Oak Ridge National Laboratory in Tennessee, seeks to understand the limits of natural processes in attenuating contaminant plumes. This understanding will help to delineate uncertainties in how recharge events affect subsurface transport of contaminants and to define the level of source zone mitigation that is required to protect human health and the environment.

- The Hanford IFRC, located at the Hanford Site in Washington State, is performing studies to resolve the geochemical, hydrophysical, and microbiologic factors that control the migration of contaminant uranium through the vadose zone and groundwater. 
The overarching challenge for the IFRC investigations is to advance scientific approaches for developing a predictive understanding of realistically complex subsurface systems.

In addition to the large IFRC projects, the ERSP also supports smaller field investigations, such as studies at the:

- Hanford $100 \mathrm{H}$ Area to assess the potential for immobilizing and detoxifying chromium-contaminated soils and groundwater using bioremediation

- F-Area of SRS to use a systems approach to make reliable and computationally tractable predictions of plume evolution and to evaluate the benefits of increasing complexity on successful predictions of contaminant mobility over stewardship timeframes

- INL to evaluate the effectiveness of strontium immobilization by microbially induced calcite precipitation.

The IFRCs and the other field projects are critical components of the ERSP research portfolio because they provide the context and motivation for many smaller scale laboratory investigations and modeling studies within the ERSP. These field projects also provide ERSP investigators with opportunities to obtain samples of environmental media for experimental purposes and opportunities to conduct short-term field experiments in well-characterized and intensively monitored environments.

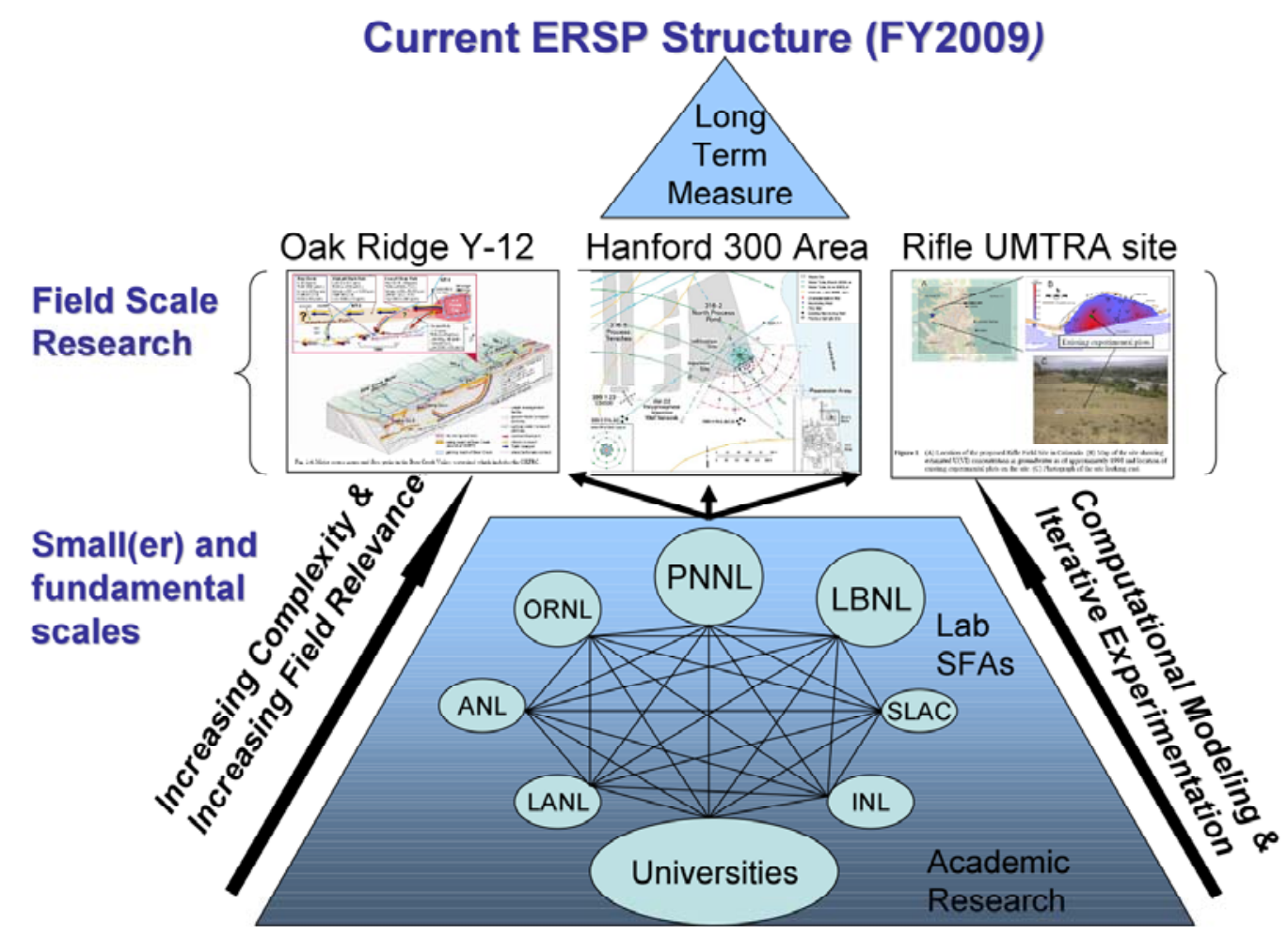

Figure 4.2. Hierarchical Structure and Coordination of the ERSP Research Program 
The ERSP also supports focused research programs at six DOE national laboratories and a diverse portfolio of research projects led by university principal investigators (PIs). The ERSP has established SFAs, which are interdisciplinary and integrated research programs in subsurface science, at the following national laboratories (http://www.lbl.gov/ERSP/generalinfo/sfa.html): Argonne National Laboratory, INL, Lawrence Berkeley National Laboratory, Oak Ridge National Laboratory, Pacific Northwest National Laboratory (PNNL), and the Stanford Linear Accelerator Center (SLAC) National Accelerator Laboratory. University-led research projects for the ERSP are selected and funded through an annual solicitation. All ERSP-funded research projects must address critical knowledge gaps with hypothesis-driven research and justify the applicability of the proposed research to understanding DOErelevant, field-scale, contaminant transport processes. All ERSP PIs and key co-PIs are required to attend the annual ERSP PI's meeting, which is also attended by staff from DOE-EM.

The overall goal of the ERSP program is to establish a scientifically validated approach to the development of predictive models of contaminant fate and transport and the development of innovative remediation measures. This requires an iterative and interdisciplinary approach to experimentation and modeling to identify and understand the key biogeochemical and hydrodynamic processes that control the transport and transformation of contaminants in DOE-relevant environments, which are typically very complex. These scientific advances will lead to improved methods to predict and mitigate the impacts of environmental contamination from past nuclear weapons production and provide a scientific basis for the long-term stewardship of nuclear waste disposal sites. 


\subsection{EM Groundwater and Soil Remediation Program}

DOE-EM is responsible for the safe and compliant disposition of legacy wastes and facilities from defense nuclear applications. A large majority of these wastes and facilities are "one-of-a-kind" and unique to DOE. Many of the programs to treat these wastes have been "first-of-a-kind" and unprecedented in scope and complexity. This has meant that the scientific basis and many of the technologies needed to successfully disposition these wastes were not yet developed or required significant re-engineering to be adapted for DOE-EM's needs. Thus, throughout its existence, DOE-EM has required a strong technology component - focused on developing technologies to enhance safety, effectiveness, and efficiency - to accomplish its mission. To maintain the focus on developing scientific underpinnings and needed technologies, DOE EM established the Engineering and Technology Program in 2006.

The overall objective of the DOE-EM Engineering and Technology Program is to reduce the technical risk and uncertainty in the Department's clean-up programs and projects. Risks are known technical issues that could prevent project success. Uncertainties are indefinite or unpredictable technical aspects of a project. To reduce those risks and uncertainties, the Engineering and Technology Program will provide technical solutions where none exist, improved solutions that enhance safety and operating efficiency, or technical alternatives that reduce programmatic risks (cost, schedule, or effectiveness). The risks and uncertainties were documented in the Engineering and Technology Roadmap published in 2008 (DOE 2008a). The roadmap, which covers program areas of waste processing, groundwater and soil remediation, deactivation and decommissioning and facility engineering, DOE spent nuclear fuel, challenging materials, and integration and cross-cutting initiatives, identifies:

- Engineering and technical risks the DOE-EM program faces over the next ten years

- Strategies DOE-EM will use to minimize these risks

- Planned outcomes of implementing those strategies.

The technical risks in the roadmap were identified by DOE EM projects, by external technical reviews, and by the DOE EM sites. EM operations are performed within a culture of disciplined project management, based on DOE Order 413.3A, Program and Project Management for the Acquisition of Capital Assets. Through program and project management approaches, technical risks and uncertainties affecting each cleanup project are identified and captured in project risk assessments. Often, identifying these risks leads to applied technology development activities by the projects themselves. DOE EM uses experts to review the progress of its major cleanup projects and to assess the maturity of evolving technologies. These reviews often identify opportunities for reducing technical risk by developing and deploying innovative or enhanced technologies. DOE EM also participates in external reviews by the National Academy of Sciences (NAS), which also serves to identify technology gaps. DOE EM asked sites to identify technical risks and uncertainties in the form of "technical needs." Several workshops were held to identify current technical needs for construction of the OET roadmap. After the workshops, the technical needs were combined with input from the other sources listed above and categorized into technical risks. These risks are divided into five program areas: Waste Processing, Deactivation and Decommissioning (D\&D), Facility Engineering, DOE Spent Nuclear Fuel (SNF), and Groundwater and Soil Remediation, the latter being the focus of this document. 
The technical risks and uncertainty for the Groundwater and Soil Remediation program were organized into categories of sampling and characterization, modeling to guide cleanup, and treatment and remediation. The four strategic initiatives that were identified in the Engineering and Technology Roadmap to address these risk and uncertainty include:

- Improved Sampling and Characterization Technologies and Strategies for multiple contaminants (organics, metals, and radionuclides) in challenging environments (e.g., around subsurface interferences, at intermediate and great depths, and in low- and high-permeability zones.

- Advanced Predictive Capabilities that incorporate chemical reactions, complex geologic features, and/or multiphase transport for multiple contaminants (organics, metals, and radionuclides) in challenging environments to provide an improved technical basis for selecting and implementing remedies.

- Enhanced Remediation Methods that reduce costs, increase effectiveness, and reduce risks to human health and the environment by employing cost-effective in situ (in-place) technologies and using natural remediation processes.

- Enhanced Long-Term Performance Evaluation and Monitoring by developing and deploying costeffective long-term strategies and technologies to monitor closure sites (including soil, groundwater, and surface water) with multiple contaminants (organics, metals, and radionuclides) to verify integrated long-term cleanup performance.

Advancements in these four major thrust areas provides the greatest opportunity for DOE to complete its legacy waste mission successfully while providing for a safe and cost-effective transition of closure sites from EM to Legacy Management (LM).

The Engineering and Technology Roadmap led to development of a program management plan (DOE 2008b). This plan describes how the OE\&T manages applied research and technology development and deployment activities to support the overall EM mission priorities. The plan provides a high-level description of OE\&T's Applied Research and Technology Development and Deployment (ARTDD) mission, vision, and strategies; a description of key management functions, systems and activities; and a discussion of interfaces with the DOE SC Office of Biological and Environmental Research (OBER) and within the EM program. The approach used by the Engineering and Technology Program is to provide technical solutions where none exist, improved solutions that enhance safety and operating efficiency, or technical alternatives that reduce programmatic risks (cost, schedule, or effectiveness).

The Engineering and Technology Program is implemented through four strategic approaches: 1) technology development and deployment, 2) engineering leadership and technical assistance, 3) leveraging, and 4) integration of engineering and technology needs. The Engineering and Technology Program works to develop solutions for technology needs identified by the sites, but not addressed by site contractors. Such technologies must stand on their own merits, be safe, cost effective, and offer significant advantages over other approaches - without introducing unacceptable levels of technical risk or schedule impact. Engineering leadership is provided through early identification and evaluation of technical maturity and technical risks, ensuring effective use of subject matter experts, resolving technical risks identified in the Engineering and Technology Roadmap, and promoting science and engineering excellence to improve project performance. Technical assistance is provided directly to sites to reduce the technical uncertainty and risk of site cleanup and includes activities such as: baseline and project reviews; technical workshops with experts on specific crosscutting issues; engineering consultation; cost 
estimation support; scientific or engineering problem solving; technical analysis and studies; assistance with technology demonstrations; testing of alternative approaches; and contract and acquisition support. Leveraging of technology development occurs through many avenues including private industry investment, as well as research conducted by other DOE offices and federal programs. Examples of such leveraging include direct application of commercially available technology (often following field testing or a demonstration under EM conditions), the modification or adaptation of a commercial technology to meet waste processing needs, or the commercialization of a technology that was originally developed by a university or national laboratory. The initial set of needs was generated at an EM Technical Integration Workshop held in October 2006 as input to the Engineering and Technology Roadmap. The objective of the workshop was to identify and prioritize EM's technical needs for the next ten years. Participants included EM Headquarters and field sites (both federal and contractor staff), other DOE programs, National Laboratories, NAS, and the Consortium for Risk Evaluation with Stakeholder Participation (CRESP), among others. These needs and the Engineering and Technology Roadmap will periodically be reviewed and updated. The roadmap was recently reviewed by the NAS with input from key external groups such as the Nuclear Regulatory Commission, Defense Nuclear Facilities Safety Board (DNFSB), Environmental Protection Agency (EPA), and state regulators (NRC 2009). The review provides advice to EM in support of the Engineering and Technology Roadmap development and implementation.

In order to provide effective integration and management of initiatives and projects, the DOE EM Office of Engineering and Technology uses an iterative process, shown in Figure 5.1

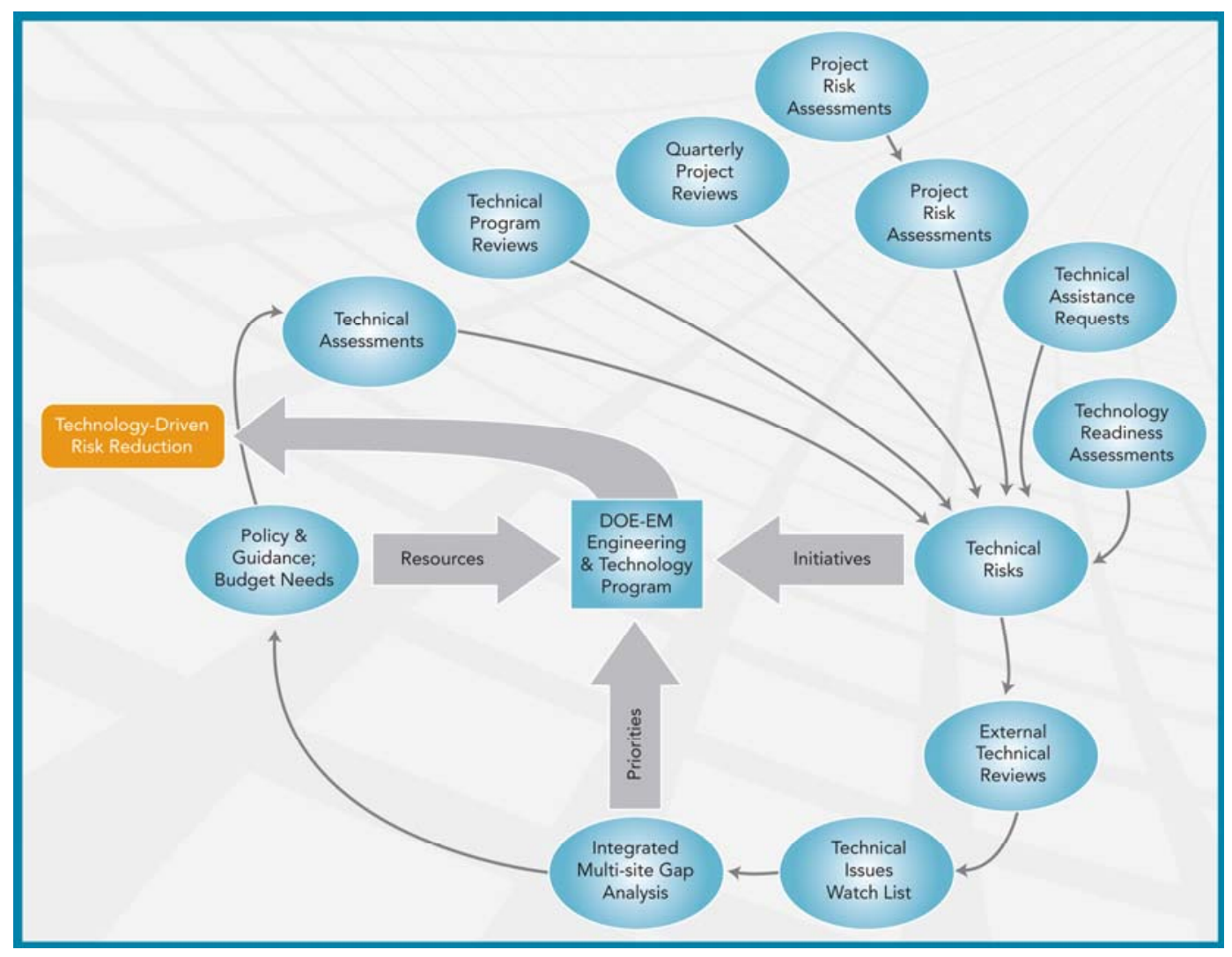

Figure 5.1. DOE EM Engineering and Technology Program Integration 
The Engineering and Technology Roadmap (DOE 2008a) and Program Plan (2008b) were based on a much larger budget than was appropriated. To address this issue, each year EM-22 develops a multi-year program plan (MYPP). The first draft of the MYPP (DOE 2008c) outlined activities from FY 2008 through FY 2010 that serves as an action or business plan for the program. Recently, specific action areas were identified to move the program forward and accomplish measurable results. These action areas are focused on 1) monitored natural attenuation of metals and radionuclides, 2) development of advanced remediation methods for metals and radionuclides (scientific and technical basis for in situ treatment systems for metals and radionuclides), 3) remediation of chlorinated solvents in the vadose zone and groundwater, and 4) mercury remediation. The attenuation-based approaches are intended to reduce or eliminate contaminant migration using naturally occurring processes, either alone or enhanced to provide sustainable remedies. In situ and enhanced attenuation technologies are being pursued to support remediation and long-term stewardship of sites contaminated with metals and radionuclides. Attenuationbased remedies are being evaluated for chlorinated solvents, including both enhanced attenuation and monitored natural attenuation. The final action area is focused on developing approaches for reducing mercury inputs to surface water to meet regulatory compliance at the ORR.

The MYPP is aligned and driven by site cleanup priorities and corresponding technical needs. The EM cleanup sites have identified technical gaps in their baselines, which, if resolved, can offer significant cost and schedule reductions to current baselines and improve safety performance for both the workers and the public. The focus is on the largest DOE cleanup sites-Hanford (both DOE Richland Operations and Office of River Protection), INL, ORR, Portsmouth, Paducah, and SRS - without losing sight of the closure sites or the smaller sites. To facilitate linkage with the sites, the Groundwater and Soil Remediation Program is responding to the needs at Hanford, INL, ORR, SRS, Paducah, and Portsmouth (Figure 5.2). Several of the WBS elements are focused on specific field sites at the SRS F Area, Hanford BC Cribs and Trenches, and ORR for mercury contamination. These field sites are different than the IFRCs funded through OBER in that they are highly leveraged with DOE EM site funding and are specifically targeted at remedial actions being investigated and implemented at those sites.

The Engineering and Technology Program also provides funding for an EM Center for Sustainable Groundwater and Soil Solutions, intended to coordinate resources for applied science and engineering activities and actively foster collaboration among DOE sites, national laboratories, other federal agencies, universities, industry, regulators, and public stakeholders. The center is also intended to serve as a bridge to bring advances in basic research into practical use, support development and testing of sustainable remediation technologies, and serve as a clearinghouse for information and a central forum for technology innovators and environmental service providers. 


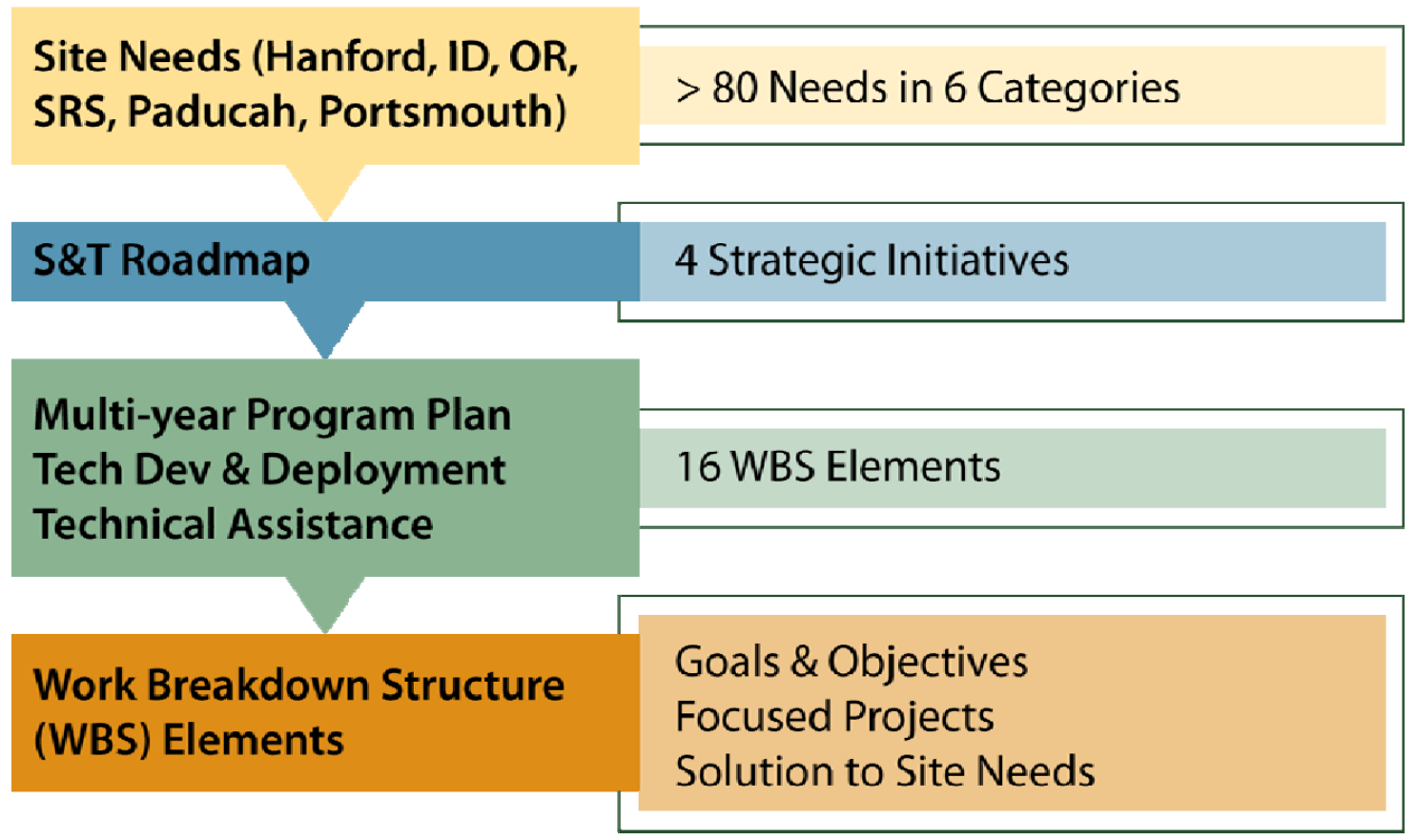

Figure 5.2. DOE's The Soils and Groundwater Remediation Program Is Designed to Solve Problems and Respond to Needs at the Following DOE Sites: Hanford, DOE/ID, ORR, SRS, Paducah, and Portsmouth 


\subsection{Path Forward: An Approach for DOE EM/SC Collaboration to Address DOE EM's Most Intractable Problems}

In a recent document (Advice on the Department of Energy's Cleanup Technology Roadmap) (NRC 2009), the NRC commented on the importance of continued research and development investments to address DOE EM's most intractable problems. During the two-year process, NRC identified three science and technology gaps that have promise for future investments by DOE EM and are relevant to ongoing basic research investments being made DOE SC in subsurface science. These included:

- Gap 1: The behavior of contaminants in the subsurface is poorly understood.

- Gap 2: Site and contaminant source characteristics may limit the usefulness of EMs baseline subsurface remediation technologies.

- Gap 3: The long-term performance of trench caps, liners, and reactive barriers cannot be assessed with current knowledge.

To address the science and technology gaps identified in the EM roadmap (DOE 2008a) and comments by NRC (NRC 2009), a diverse team of scientist was convened to examine DOE EM science challenges and opportunities. This team recommended a tiered systematic approach that bridges the gap between basic science and applied research and links science to EM cleanup activities.

Bridging the gap between basic science and "needs driven" applied research is a universal challenge for all areas of technology development. Bridging this gap is particularly challenging when confronting intractable problems such as the environmental cleanup of the DOE complex, for which there are not well established economic incentives for translating basic science advances into commercial products and services. Therefore, it is incumbent upon the DOE to facilitate this transition of scientific results into applied solutions. This section discusses the distinct roles for DOE's basic science (SC) and applied research (EM) programs on contaminant fate and transport, with a specific focus on basic and applied field research activities at several DOE sites. Lastly, we outline how increased resources could be used by EM to further leverage basic science advances towards the solution of DOE's currently intractable environmental problems.

The motivation and goals for DOE's basic science and applied research programs in subsurface science are summarized in Figure 6.1. As described in Section 4.0, the motivation of basic science is to develop a deeper understating of fundamental processes and to continually advance the state-of-thescience (i.e., knowledge) without specific time constraints. In contrast, applied research uses existing scientific principles and discoveries obtained through basic science to solve site-specific problems and to guide remediation and management strategies at a broad range of contaminated sites. The motivation for "needs driven" applied research is to address site-specific challenges that prevent successful implementation of sustainable remediation strategies. 


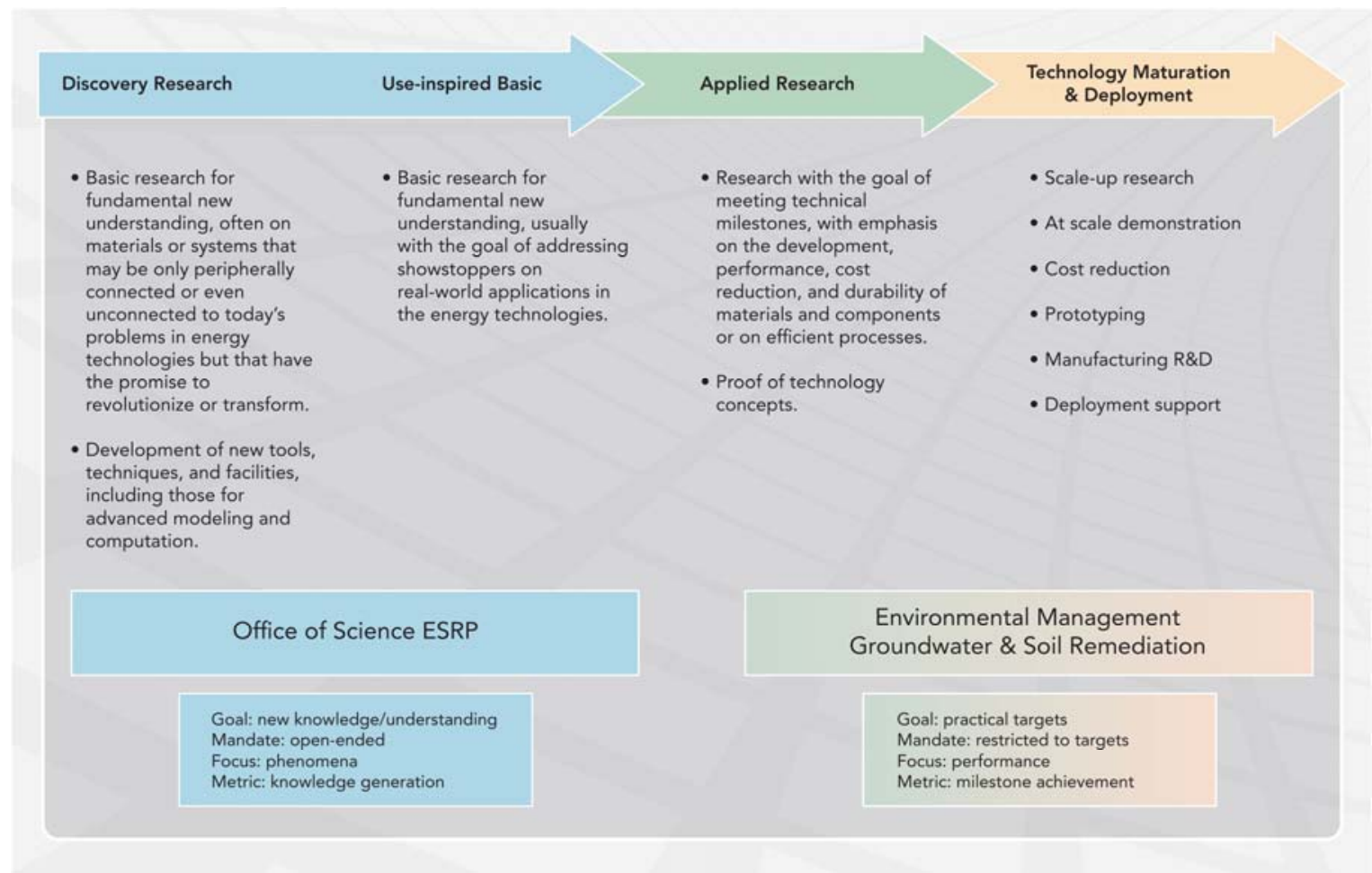

Figure 6.1. Interface Between Basic Science (SC) and Applied Research (EM) in Subsurface Science

Although the basic science and applied research programs have distinct motivations and goals, the objectives of these programs can be classified into common crosscutting themes. The five crosscutting themes provided below summarize key challenges for basic science and applied research to advance our understanding of contaminant fate and transport and to develop solutions for DOE's environmental problems. The five scientific theme areas and the approach by both OBER and OE\&T are:

\section{- Understanding and Overcoming Heterogeneity}

o OBER: Develop improved approaches and techniques to characterize the key physical, chemical and biological properties with sufficient spatial coverage and resolution to adequately constrain predictive models of contaminant fate and transport. Specific challenges include the advancement of geophysical, geochemical, microbiological characterization techniques as well as process-based approaches for interpreting and integrating the disparate data sets collected over widely varying scales of observation.

o OE\&T: Apply state-of-the-science approaches and techniques to characterize the biogeochemical and hydrodynamic properties that control contaminant flow and transport to develop and improve existing site specific conceptual and predictive models. Optimize and field test these approaches and techniques to identify contaminant source zones and determine the impact of subsurface heterogeneity on large scale plume behavior under fluctuating hydrologic and biogeochemical conditions. Apply and field test new and existing geophysical and sensor tools to characterize heterogeneity and plume location. Apply, adapt, and incorporate new data integration methods to update existing site specific conceptual models. Integrate and translate basic research findings into a useable form for site managers to improve the existing site conceptual model. 


\section{- Identifying, Understanding, and Evaluating the Key Biogeochemical and Hydrodynamic Controls on Contaminant Behavior Under Varying Conditions}

o OBER: More fully understand, through iterative experimentation and modeling, the emergent processes and properties which control contaminant fate and transport across multiple scales in subsurface systems. Develop an improved understanding of the key biogeochemical and hydrodynamic mechanisms, rates and processes controlling contaminant mobility (or immobility) in subsurface materials under relevant biogeochemical and hydrogeological conditions.

o OE\&T: Apply state-of-the-science approaches and techniques to describe the biogeochemical and hydrodynamic mechanisms, rates, and processes controlling contaminant behavior in complex subsurface environments. Optimize the broadly applicable process level detail, developed through basic science, to address contaminant behavior under site specific conditions at the field scale. Integrate and translate basic research findings into a useable form for site managers to improve existing site conceptual model. Incorporate these findings into EM project baseline site specific documentation to improve the technical foundation for site remediation decisions.

\section{- Applying Predictive Models to Understand Contaminant Behavior and to Support Developing} and Implementing Effective and Sustainable Remediation Approaches

o OBER: Develop robust computational models using state-of-the-art computational resources to refine predictions of contaminant fate and transport in DOE relevant hydrogeologic settings.

Develop scaling methods to link small scale influences on contaminant mobility with larger scale computational domains. Develop approaches to experimentally test advanced computational models and to assess the importance of increased model complexity and resolution in predicting the system behavior.

o OE\&T: Apply state-of-the-science subsurface models that are sufficiently robust to capture key hydrodynamic and biogeochemical processes that control contaminant fate and transport.

Improve existing site specific models by incorporating the appropriate amount of spatial and temporal resolution and process detail required to improve the technical credibility of site specific predictions. Incorporate new scaling and data integration approaches and tools to improve predictions of plume and system behavior before, during, and after a remedial action.

\section{- Developing New Approaches for Sustainable Remediation}

o OBER: Develop new approaches to immobilize or remove contaminants from the subsurface. Develop a predictive understanding of current approaches to subsurface remediation.

o OE\&T: Scale remedial approaches from the laboratory to the field scale. Apply new or existing tools and approaches that improve the ability to treat low porosity zones with remedial technology. Evaluate the long-term impact of remedial options on the stability of immobilize phases and conduct post test characterization at the lab and field scale to optimize the remedial approach. Integrate and translate basic and applied research findings to optimize remedial approaches and to provide a sound technical basis for natural or enhanced attenuation.

\section{- Monitoring Remediation Performance Over Stewardship Time Frame}

o OBER: Develop integrated and multi-scale approaches to monitor subsurface biogeochemical and hydrodynamic processes and to test predictive models. Investigate new methods to track remediation performance and the long term sustainability of remediation strategies. 
O OE\&T: Apply state-of-the-science approaches to verify long-term performance of remedial systems and/or natural attenuation and develop a technical basis for transitioning waste sites from active to passive remediation.

In addition to the above crosscutting themes, several examples have been created to illustrate the coordination of SC's basic science and EM's applied research programs in subsurface science. One of the six integration examples, mercury at the Oak Ridge Y-12 Complex, is discussed next. For a review of the other examples, see Appendix A. The examples discussed in this document do not represent an exhaustive list of the challenges faced by DOE EM. Their purpose is to illustrate how investments in both basic and applied research programs can leverage off one another to both advance scientific understanding and develop solutions for some of DOE's most difficult and costly environmental problems. 


\subsection{Oak Ridge Reservation: Oak Ridge Mercury Research Integration Example}

At ORR, operations at the Y-12 Plant from 1950 to the early 1960s resulted in the release of about 108,000 to $212,000 \mathrm{~kg}$ of mercury into the EFPC (CDM 1996), which was distributed locally in stream sediments, floodplain soils, and ground and surface waters. Although the primary mercury discharges from the Y-12 Plant stopped in 1963, a small amount of mercury continues to enter EFPC, originating from point-sources at the Y-12 Complex (Southworth et al. 2000; Campbell et al. 1998). The portion of EFPC that occurs within the Y-12 NSC and the boundary of the city of Oak Ridge is generally referred to as "Upper EFPC" (UEFPC).

The ORR was placed on the U.S. National Priorities List as a Comprehensive Environmental Response, Compensation, and Liability Act (CERCLA) site in 1989 requiring a Remedial Investigation (RI)/Feasibility Study (FS) to test compliance with regulated water quality criteria. The current U.S. National Pollution Discharge Elimination System (NPDES) permit for Y-12 under the Clean Water Act (CWA) sets a water quality limit for total mercury at $51 \mathrm{ng} / \mathrm{L}$ for the protection of fish and aquatic life. Due to difficulties in achieving compliance with this limit in UEFPC, DOE has appealed for a compliance limit of 5 gram/day (g/d) of total mercury discharge for Y-12 Plant discharges, which is equivalent to an in-stream mercury concentration of approximately $200 \mathrm{ng} / \mathrm{L}$ based on the 90 -day average daily base water flow. To meet the $5-\mathrm{g} / \mathrm{d}$ limit, DOE had been systematically working to reduce mercury losses under the Reduction of Mercury in Plant Effluents (RMPE) program. The RMPE program was specifically designed to reduce total mercury discharges from the Y-12 facility into UEFPC (CDM 1996). Remedial actions included filling and capping a contaminated pond, renovating and replacing subsurface storm and process drains, collecting and treating contaminated sump waters, stabilizing eroding stream banks, and bypassing EFPC around a small impoundment (CDM 1996; Southworth et al. 2000).

Despite these efforts, mercury contamination and its accumulation in fish continue to be a problem over a large spatial extent on the ORR. Mercury continues to be released from contamination from the Y-12 Complex, with a point source at the headwater of EFPC and other diffused sources, including contaminated sediment in the UEFPC. The sediment-borne mercury is susceptible to changing flow conditions in the creek.

The OE\&T Groundwater and Soil Remediation Program initiated a technology demonstration at the Y-12 field site, focusing on developing strategies and treatment technologies that reduce the concentration and loading of waterborne mercury in UEFPC. In summer 2008, two types of studies took place: 1) hydraulic manipulation in UEFPC to reduce mercury mobilization from contaminated stream sediments and 2) in situ chemical treatment of contaminated source waters to decrease mercury discharge to UEFPC. The initial results from the 2008 study suggest that a combination of reducing the augmented flow volume and chemically reducing mercury with stannous chloride will produce $\sim^{1 / 3}$ reduction in baseflow mercury loading to UEFPC, from approximately $8 \mathrm{~g} / \mathrm{d}$ to $5 \mathrm{~g} / \mathrm{d}$. Research in 2009 and beyond will seek further improvements in the identification of mercury sources originating through groundwater, sediment, and surface water interactions.

With increased regulatory focus on reducing mercury in fish, new approaches and technologies are needed to reduce mercury methylation and subsequent bioaccumulation. In general, methylmercury 
production is dependent on the concentrations and speciation of $\mathrm{Hg}(\mathrm{II})$ available for biotic and abiotic transformation in aquatic environments. The mercury speciation and transformation mechanisms in the impacted area on the ORR are extremely complicated, particularly in the microenvironment of watersediment interface where a variety of biogeochemical reactions may occur. Fundamentally, there is lack of understanding of 1) how mercury is transformed at the sediment-water interface by coupled chemical and microbiological processes, 2) the relevant rates of various abiotic and microbiologic transformations, and 3) the controls on the net methylmercury production.

The goal of the ERSP-funded SFA program at Oak Ridge National Laboratory (ORNL) is to elucidate the mechanisms by which inorganic mercury is transformed into methylmercury, particularly the processes controlling methylmercury production at contaminated sites. The SFA project has begun a field and laboratory study by integrating field characterization, geochemistry, microbiology, molecular sciences, and high-performance computational simulation. Subcellular biomolecular-scale research will focus on structure, function, and dynamics in microorganisms.

By emphasizing mechanistic-driven, high-impact research, the SFA addresses the key local concern of mercury transformation to methylmercury, which subsequently bioaccumulates in fish on the ORR. ORNL's SFA research will produce scientific understanding that is required for developing and implementing alternative strategies for controlling methyl mercury production, complementing the current approach of source reduction that is being explored in the OE\&T Groundwater and Soil Remediation Program at ORNL.

Although the current focus is on waterborne mercury in UEFPC, future efforts will investigate novel treatments of mercury in soils, which are the ultimate source of mercury on ORR. The EM Groundwater and Soil Remediation program will identify, test, and demonstrate the impact of soil amendment-based remedial strategies that impede mercury bioavailability. Technical targets include 1) using in situ soil amendment strategies in saturated/ vadose zone regimes to control mercury fate and transport, and 2) using ex situ mercury remedial techniques to assist with targeted soil and sediment removal strategies in mercury-contaminated systems.

Source identification and advanced modeling is another theme of EM's future investment where the applied R\&D program aims to identify, test, and demonstrate the importance of groundwater/surface water interactions on mercury fate and transport. This effort complements the planned Integrated Facility Disposition Project (D\&D investment) by providing a systems approach to assess contaminant migration pathways. The interaction among EM-22, ERSP, and DOE EM site operations can combine the knowledge and evaluate the impact of mercury sources on remedial strategies that impede mercury bioavailability and bioaccumulation. Specific targets include 1) identifying mercury sources using transport pathways and groundwater/surface water interactions relevant to mercury remediation, 2) using characterization techniques to assist with targeted soil and sediment removal strategies in mercurycontaminated systems, and 3) improving existing conceptual models for mercury fate and transport in an effort to guide predictive models and decision-making strategies with regards to remediation in groundwater, surface water, and vadose zone regimes. Figure A.1 shows the integration and collaboration between DOE EM and ERSP activities at the Y-12 Complex. 


\section{OAK RIDGE Y-12 COMPLEX EM AND ERSP LINKAGES}

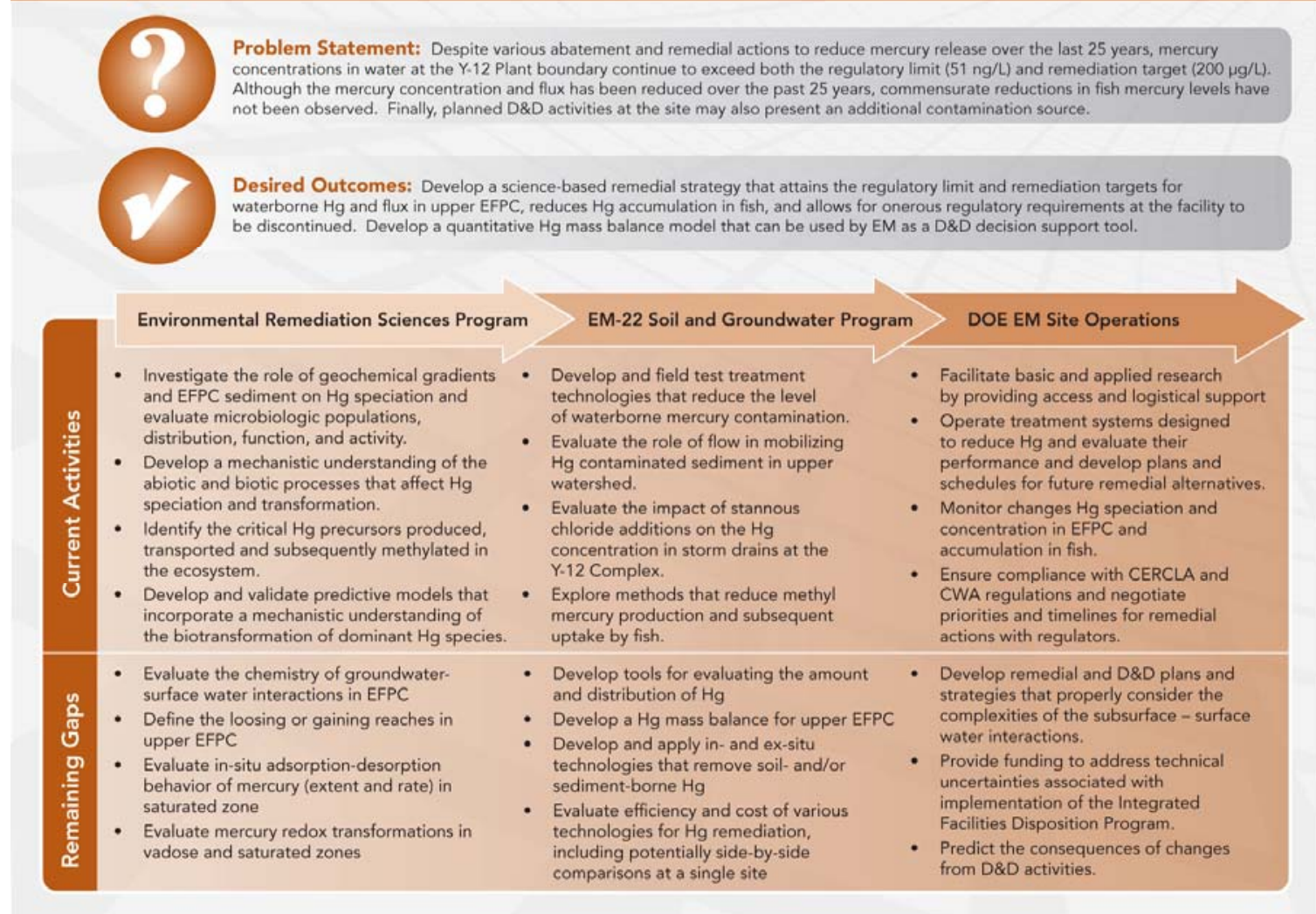

Figure 6.2. Oak Ridge Y-12 EM and ERSP Linkages for Mercury

\subsection{Proposed Strategy to Leverage Basic Science and Applied Research Investments}

The NRC review of the Engineering and Technology Roadmap identified that for OE\&T to have a successful applied research program, partnering and leveraging with other relevant organizations will be required (NRC 2009). As described in the Oak Ridge example, coordination and cooperation between the DOE EM and SC subsurface science programs provides an effective approach that can be used to address challenges currently facing DOE. Therefore, it is essential for EM and SC staff members, who are responsible for managing DOE's basic and applied subsurface science research programs, to communicate through activities such as:

- Participating in regular formal and informal meetings between program managers to communicate program direction and significant research findings, and to discuss emerging issues

- Participating in periodic informal technical exchanges to communicate basic and applied research findings by the Principal Investigators involved in each program

- Participating in the ERSP's annual PI meeting and EM-20's annual review meeting 
This communication and coordination strategy, if done effectively, will prevent duplication of efforts and maximize the opportunity for a portion of ERSP's basic science to be transferred and leveraged by DOE EM's applied research program. The complimentary approach discussed in the Oak Ridge Y-12 Complex integration example for mercury and the proposed leveraging strategy are not intended to determine program direction, but they will help influence it. Additionally, this approach and strategy will help to foster a dialogue between basic and applied research in subsurface science to establish the scientific foundation needed to make sound and defensible remedial decisions that are acceptable to regulators and will successfully meet the target cleanup goals for DOE EM's most intractable problems. 


\subsection{References}

Abraham S. 2002. "Statement of The Honorable Spencer Abraham Secretary of the US Department of Energy." In: Committee on Armed Services, United States Senate ed.; Washington, DC.

Bredt P, AR Felmy, PA Gauglitz, D Hobbs, S Krahn, N Machara, M Mcllwain, BA Moyer, AP Poloski, K Subramanian, JD Vienna, and B Wilmarth. 2008. Scientific Opportunities to Reduce Risk in Nuclear Process Science. PNNL-17699; Pacific Northwest National Laboratory: Richland, Washington.

Campbell KR, CJ Ford, and DA Levine. 1998. "Mercury distribution in Poplar Creek, Oak Ridge, Tennessee, USA.” Environ Toxicol Chem 17(7):1191-1198.

Congress. 2006. "Energy and Water Development Appropriations Act." Conference Report on H.R. 2419.

CDM Federal Programs Corporation. 1996. LMES Mercury issues related to NPDES and the CERCLA watershed project at the Oak Ridge Y-12 Plant; Y/ER/MS-4; Oak Ridge, Tennessee, prepared for the U.S. Department of Energy (DOE), Office of Environmental Management.

DOE (see U.S. Department of Energy)

Freeze RA, and JA Cherry. 1979. Groundwater. Prentice Hall: Upper Saddle River, New Jersey.

Freshley M, AL Bunn, GW Gee, TJ Gilmore, CT Kincaid, RE Peterson, AL Ward, SB Yabusaki, and JM Zachara. 2002. Groundwater Protection Program Science and Technology Summary Description. PNNL-14092, Pacific Northwest National Laboratory: Richland, Washington.

Looney BB, and RW Falta. 2000. Vadose Zone Science and Technology Solutions. Volume I and II. Battelle Press, Columbus, Ohio.

National Research Council (NRC). 2005a. Improving the Characterization and Treatment of Radioactive Wastes for the Department of Energy's Accelerated Site Cleanup Program. National Academies Press, Washington, D.C.

National Research Council (NRC). 2005b. Risk and Decisions about Disposition of Transuranic and High Level Radioactive Waste. National Academies Press, Washington, D.C.

National Research Council (NRC). 2009. Advice on the Department of Energy's Cleanup Technology Roadmap: Gaps and Bridges. National Academies Press, Washington, D.C., Prepublication Copy: Subject to Editorial Revision.

Rucker DF, and MW Benecke. 2006. Geophysical Investigations by High Resolution Resistivity for the BC Cribs and Trenches Area, 2004-2006. D\&D-31659, Rev. 0; Fluor Hanford Inc., Richland, Washington. 
Southworth GR, RR Turner, MJ Peterson, MA Bogle, and MG Ryon. 2000. "Response of mercury contamination in fish to decreased aqueous concentrations and loading of inorganic mercury in a small stream.” Environ Monit Assess 63(3):481-494.

U.S. Department of Energy (DOE). 1996. The 1996 Baseline Environmental Management Report (Volume I and II). DOE/EM-0319; Office of Environmental Management: Washington, D.C.

U.S. Department of Energy (DOE). 1997. Linking Legacies: Connecting the Cold War Nuclear Weapons Processes to Their Environmental Consequences. DOE/EM-0319; U.S. DOE Office of Environmental Management: Washington, D.C.

U.S. Department of Energy (DOE). 1998a. Accelerating Cleanup: Path to Closure. U.S. DOE Office of Environmental Management, Washington, D.C.

U.S. Department of Energy (DOE). 1998b. Groundwater/Vadose Zone Integration Project Science and Technology Summary Description. DOE/RL-98-48, Vol. 3, Rev. 0, DOE/Richland Operations: Richland, Washington.

U.S. Department of Energy (DOE). 2000a. Status Report on Paths to Closure. DOE/EM-0526; U.S. DOE Office of Environmental Management: Washington, D.C.

U.S. Department of Energy (DOE). 2000b. Groundwater/Vadose Zone Integration Project Science and Technology Summary Description. DOE/RL-98-48, Vol. 3, Rev. 1; DOE/Richland Operations: Richland, Washington.

U.S. Department of Energy (DOE). 2001. A National Roadmap for Vadose Zone Science \& Technology: Understanding, Monitoring, and Predicting Contaminant Fate and Transport in the Unsaturated Zone. DOE/ID-10871, Rev. 0; DOE/Idaho Operations Office, Idaho Falls, Idaho.

U.S. Department of Energy (DOE). 2008a. Engineering \& Technology Roadmap: Reducing Technical Risk and Uncertainty in the EM Program. U.S. DOE Office of Environmental Management: Washington, D.C.

U.S. Department of Energy (DOE). 2008b. Engineering \& Technology Program Management Plan. U.S. DOE Office of Environmental Management: Washington, D.C.

U.S. Department of Energy (DOE). 2008c. Integrated Multi-Year Program Plan (FY 2008 - 2010). U.S. DOE Office of Environmental Management: Washington, D.C. 
Appendix A

Examples of DOE Groundwater and Soil/ERSP Integration to Address DOE EM's

Most Intractable Problems 


\section{Appendix A: Examples of DOE Groundwater and Soil/ERSP Integration to Address DOE EM's Most Intractable Problems}

Discussed in this appendix are five examples that describe the types of research coordination and integration that currently exist between DOE EM's Groundwater and Soil Remediation Program and ERSP within DOE SC. The examples represent how both programs intend to leverage off one another to bridge the gap between basic science and applied research. These examples include the Savannah River Site F-Area, uranium in the Y-12 complex affecting Upper East Fork Popular Creek (EFPC) at the Oak Ridge Reservation, and the 100-D and -H Areas, 300 Area, and BC Cribs and Trenches at the Hanford Site. Each example represents one of the applied science research sites. Although these examples do not represent an exhaustive list of the challenges for DOE EM, they do provide a clear and concise illustration of how results produced through basic science (ERSP) and "needs driven" applied research (Groundwater and Soil Remediation Program) will be translated to problem holders and influence cleanup decisions at select DOE EM sites. The complimentary approach discussed in each example below is needed to make sound and defensible remedial decisions that are acceptable to regulators and will successfully meet the target cleanup goals for DOE EM's most intractable problems.

\section{A.1 Savannah River Site: F-Area Research Integration Example}

Contaminant plumes in groundwater beneath the F-Area of SRS were created by the disposal and leakage of low-level radioactive solutions into seepage basins (Killian et al. 1987; Fenimore and Horton 1972). The plumes extend from the basins approximately 600 meters downgradient to a stream and contain a large number of contaminants. From a risk perspective, the most important contaminants include ${ }^{90} \mathrm{Sr}$, U isotopes, ${ }^{129} \mathrm{I},{ }^{99} \mathrm{Tc}$, tritium, and nitrate. Disposal of the acidic solutions (average influent $\mathrm{pH}$ of 2.9) into the basins began in 1955 and continued until 1989. The groundwater remains acidic, with $\mathrm{pH}$ values as low as 3.2 near the basins. As a result, the Atlantic Coastal Plain aquifer sediments that underlie the F-Area have been altered by acidic solutions for about 40 years. The basins were closed and capped in 1991, and a pump-and-treat remediation system began operation in 1997. In 2004, the pumpand-treat system was replaced by a hybrid funnel-and-gate system that was installed about $300 \mathrm{~m}$ from the stream. Alkaline solutions are now being injected into the gates in an attempt to neutralize the acidic groundwater (Figure A.1). 


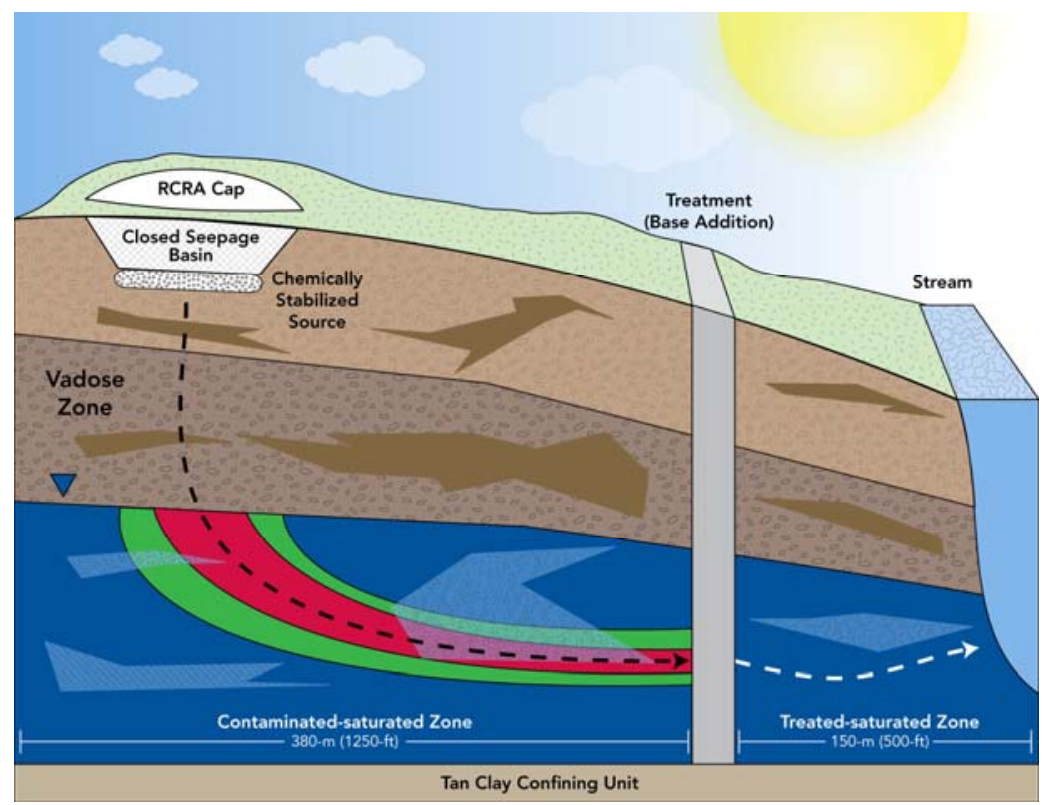

Figure A.1. Example of F-Area Seepage Basin Remediation

EM Site Operations at the Savannah F-Area are considering monitored natural attenuation (MNA) as a long-term closure strategy; near-term objectives focus on the plume located upgradient of the wetlands and base injection zone. It is recognized that mobile gradients can develop at the leading and trailing edges plumes (such as the $\mathrm{pH}$ gradient at the F-Area plume) and that such gradients can lead to transformations (such as solid phase changes) that can occur preferentially as a function of the initial hydrogeochemical heterogeneity of the system. A driving hypothesis of a collaborative Office of Science SFA (Lawrence Berkeley National Laboratory [LBNL]) and EM-22 (Savannah River National Laboratory [SRNL]) supported effort is that developing a predictive understanding of the plume $\mathrm{pH}$ gradients and their impact on key contaminant mobility over stewardship timeframes is critical for assessing whether MNA is a viable and sustainable remediation strategy at the site. However, due to the great simplifications that are typically made in the representation of heterogeneity and biogeochemical processes as needed to parameterize reactive transport models, predictions of plume migration are often not sufficiently reliable to be used to defend MNA strategies.

To reconcile this limitation, the SRNL-LBNL collaborative effort is developing and testing a multiscale strategy to characterize subsurface sediments that have similar characteristics and mechanisms relevant to reactive transport (such as distribution of surface-reactive minerals, effective surface area, mineralogy, hydrogeological properties, and sorption/precipitation mechanisms). This concept will enable the integration of laboratory-based information about biogeochemical mechanisms with field-scale information about aquifer geometry and properties. It takes advantage of the (nonrandom) spatial distribution of geological units and the linkage between hydrophysical and geochemical properties that often exists in nature due to depositional processes. The LBNL SFA effort will use the reactive-facies based characterization approach to parameterize mechanistic reactive transport models, which will be used to predict contaminant mobility over stewardship timeframes (i.e., as the acidic groundwater is replaced by more neutral $\mathrm{pH}$ groundwater: the trailing plume concept). Using the model, the LBNL SFA will also formally evaluate the benefit of increasing complexity on successful predictions of contaminant mobility. The SRNL effort will assess the value of the gradient and reactive-facies constructs for 
assessing the viability of MNA-based remedies and will develop an associated screening tool. The SRNL team will use the screening tool or a combination of more complex models, depending on the outcome of this effort. The resulting modeling approach will be used to communicate with stakeholders and operations personnel about the viability of MNA as a sustainable strategy at the F-Area. The success of these approaches at the F-Area site can be transferred across the DOE complex to help sites incorporate aquifer heterogeneity and MNA-remedies into their clean-up decision making process. Figure A.2 describes the integration and collaboration between EM and ERSP activities at the SRS F-Area.

\section{SAVANNAH RIVER SITE F-AREA EM AND ERSP LINKAGES}

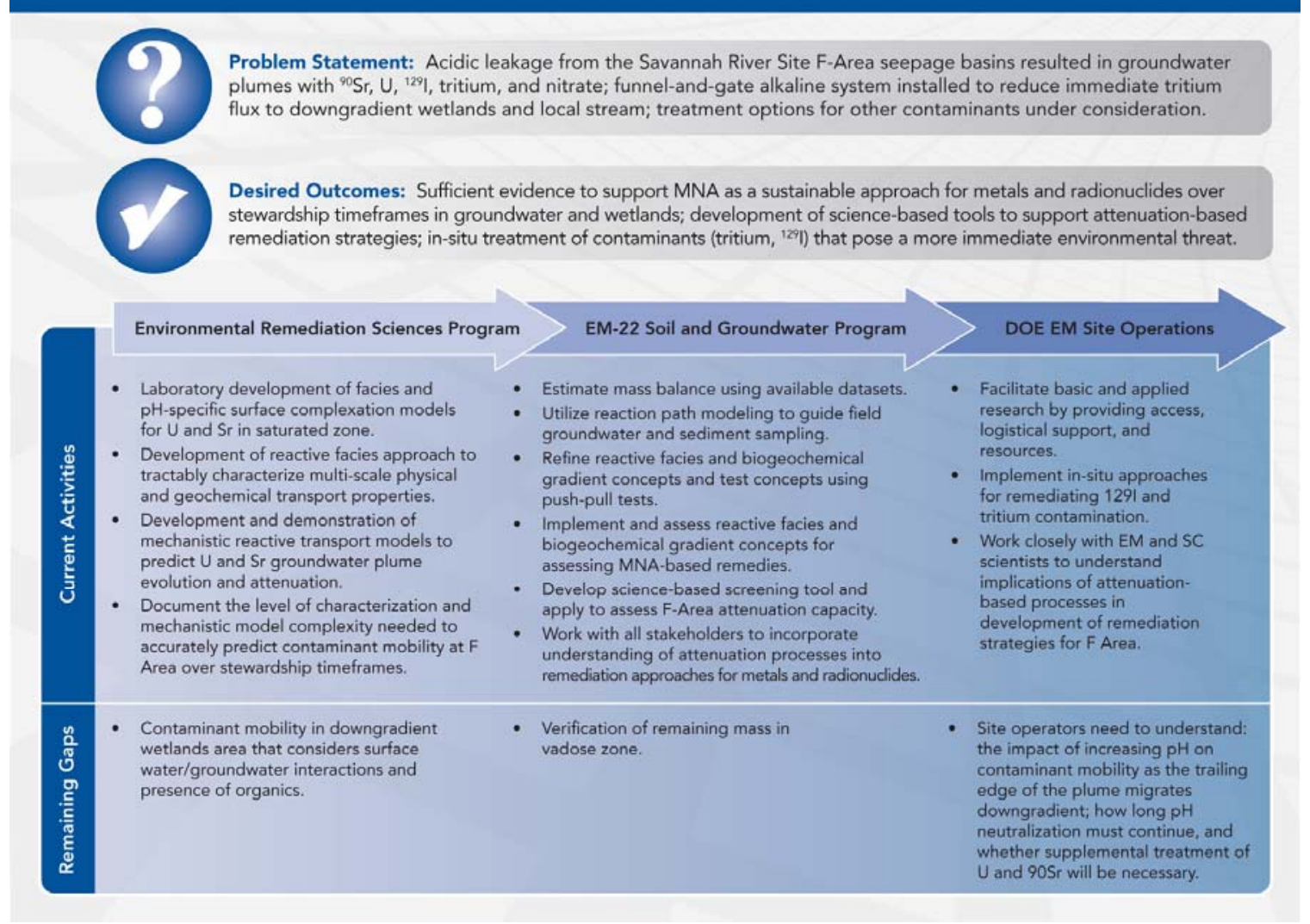

Figure A.2. SRS EM F-Area EM and ERSP Linkages 


\section{A.2 Oak Ridge Reservation: Oak Ridge Uranium Research Integration Example}

The uranium-contaminated areas of the Y-12 site on the ORR include a groundwater plume that originated from the former S-3 Waste Disposal Ponds and solid and liquid U waste disposal in the Bear Creek Burial Grounds. The Ponds received $3.2 \times 10^{8}$ liters of acidic, nitrate and uranium-bearing waste for 32 years until the Ponds contents were "neutralized," "denitrified," and capped in 1988. Although the Ponds are capped, the vast majority of contaminant mass has migrated away from the Ponds into the underlying geologic media where it has precipitated or adsorbed onto the solid phase or migrated into the matrix via diffusion, creating an extensive secondary source of contamination. Groundwater interaction with this secondary source of contamination has resulted in a relatively stable groundwater plume that extends over 4 kilometers down Bear Creek Valley. Contaminants in the groundwater plume include U,

${ }^{99} \mathrm{Tc}$, nitrate, thorium, and volatile organic compounds such as acetone, methylene chloride, toluene, and tetrachloroethylene (DOE 1997). The groundwater $\mathrm{pH}$, which can range from 3.2 close to the Ponds to over 7.0 in wells farther downgradient, is postulated to have a tremendous impact on subsurface processes and contaminant fate and transport. Elevated levels of dissolved organic carbon (DOC $>200 \mathrm{ppm}$ ), primarily acetate leftover from Pond treatment, and hydrogen $(>40,000 \mathrm{ppmv})$ are also associated with the plume. Other fixed gases recently detected in groundwater include significant quantities of $\mathrm{CO}_{2}, \mathrm{CO}$, $\mathrm{N}_{2} \mathrm{O}, \mathrm{N}_{2}$ and $\mathrm{CH}_{4}$. Dissolved oxygen is typically low $(<1 \mathrm{ppm})$ in deeper more contaminated groundwater zones but can be higher ( 2 to $4 \mathrm{ppm}$ ) in areas subject to shallow recharge.

The disposal of $U$ in the Bear Creek Burial Grounds occurred from 1956 to 1991. It contained solid and liquid waste such as large pieces $U$ metal, $U$ turnings and chips bathed in oil, and saw fines. Inventories were massive and on the order of $18.6 \times 10^{6} \mathrm{~kg} \mathrm{U}(90 \%$ as $\mathrm{U}$ metal). The $\mathrm{U}$ metal is pyrophoric under normal environmental conditions and historical photographs and anecdotal evidence of U tailings igniting and burning in trenches were commonplace. The sites were closed from 1989 to 1994, and RCRA caps were installed. Since many of the trenches were below the water table a good portion of the year, seepage of $U$ into groundwater and surface water has been persistent for many years. The hydrogeological setting at the burial grounds is conducive to contaminant migration and groundwater contamination. Seeps from capped areas reflect surface water-groundwater connection and coupling with recharge events. As well, the known corrosion of the buried $\mathrm{U}^{0}$ generates $\mathrm{H}_{2}$, and heat and microbial degradation of (cyclo)alkanes from the co-disposed oil produces potential ligands that may accelerate $U$ migration.

The ERSP and EM research programs provide valuable information on source migration processes and/or attenuation processes at many of DOE's contaminated sites, establishing a scientific and technical basis for decisions on actions to be taken. A knowledge-based approach helps resolve some of DOE's large-scale, currently intractable problems by providing field-validated methods and predictive tools for determining if remediation schemes employed at contaminated sites are technically viable over time and whether natural attenuation can achieve cleanup goals in subsurface environments of concern (DOE 2006). Such a robust approach would also assist with the validation of predictive models and the design of remedial strategies and long-term stewardship monitoring. The work further meets the high-priority science and technology needs specified by the Office of Legacy Management, i.e., "knowledge of fate and transport mechanisms and predictive capabilities." 
As well, the research efforts are an integral part of Climate and Environmental Sciences Division (CESD's) Strategic Plan, which addresses "those fundamental issues where basic research can have a significant impact on characterization, assessment, cleanup, and stewardship at DOE sites" (DOE 2006). This work addresses many of the scientific needs outlined in the ERSP Strategic Plan. Specifically, it provides new experimental and numerical knowledge and information in previously unexplored areas of in situ contaminant natural attenuation rates and mechanisms and long-term effectiveness of remedial activities to support CESD and EM's mission of long-term isolation, in situ remediation, and stewardship of contaminated sites. It also provides predictive tools for assessing the in situ rates and mechanisms of contaminant natural attenuation and remediation at numerous sites throughout the DOE complex.

EM activities on the ORR have developed a Groundwater Strategy with the formation of an ORR Groundwater Technical Core Team to "facilitate the identification, funding, and implementation of highpriority science and technology investigations." This team works with state regulators, remediation contractors, and the DOE ORR Closure Project Core Teams to focus efforts on the goal of site closure. DOE's Oak Ridge Operations (ORO) EM staff are charged with implementing the ORR Groundwater Strategy and have requested ERSP project leads to participate in the Groundwater Core Team.

Characterization data from the ERSP ORFRC will also be input into the Oak Ridge Environmental Information System (OREIS), which is the long-term repository for characterization data generated by the ORR EM and compliance programs. By periodically providing the ORFRC data to OREIS, we will ensure the long-term retention and use of the data by EM for making ORR environmental restoration decisions.

In summary, the research generated by the ERSP Oak Ridge Integrated Field Challenge (ORIFC) research plan will directly help the ORR EM program fulfill the science and technology needs specified in the ORR Groundwater Strategy as prerequisites for making final groundwater remediation decisions. This research will be completed on a schedule that will provide maximum input to upcoming remediation decisions. Two mechanisms provide input directly to the decision-making process: team membership on the ORR Groundwater Core Team; and regularly inputting Oak Ridge Field Research Center (ORFRC) data into the EM OREIS database. There is strong support from ORO DOE EM and SC, the EM contractor (Bechtel Jacobs Company [BJC]), and public stakeholders that explicitly state that ERSP research findings from the ORFRC will be used to make remediation decisions. Figure A.3 describes the integration and collaboration between EM and ERSP activities at the Oak Ridge Y-12 Complex for Uranium. 


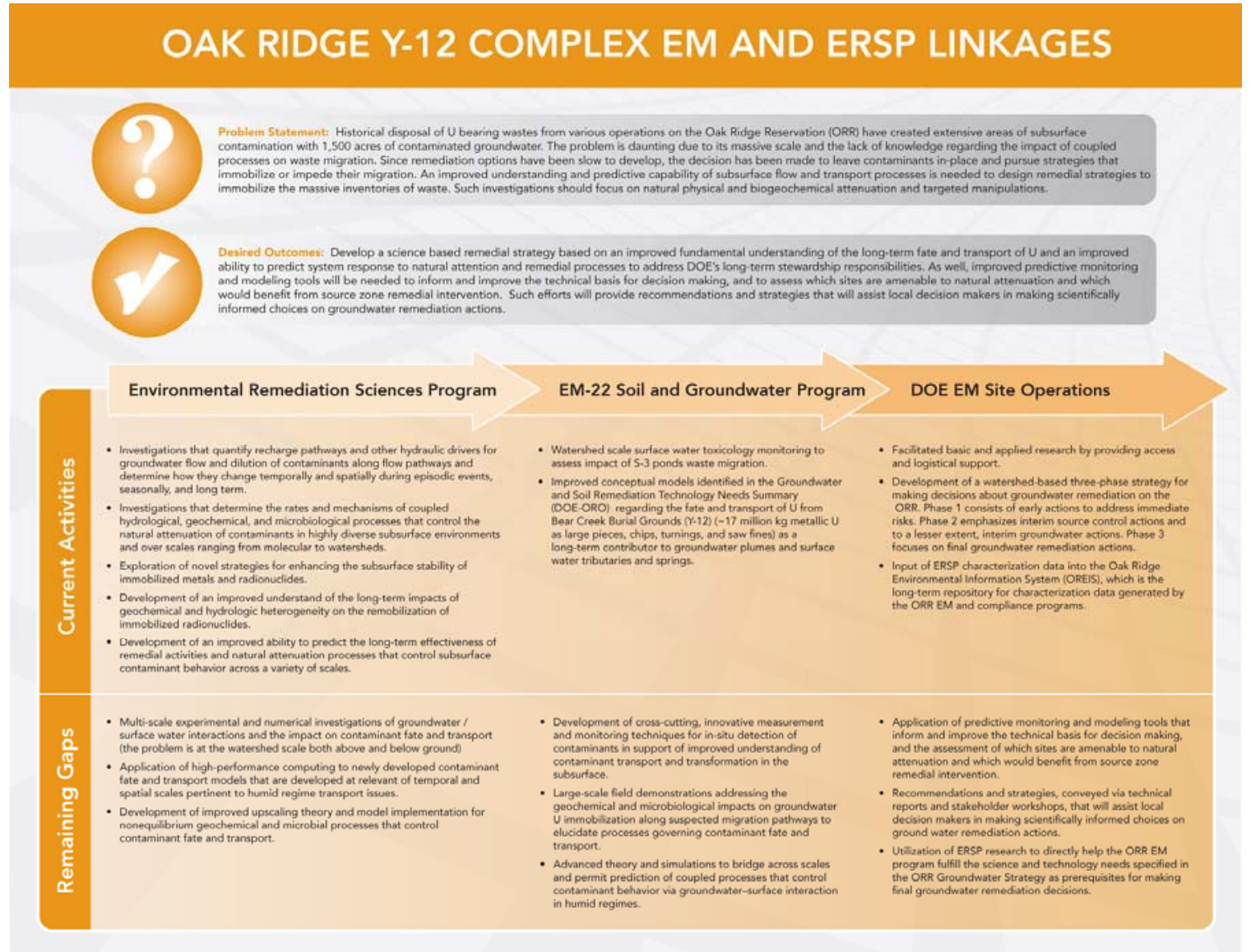

Figure A.3. Oak Ridge Y-12 Complex EM and ERSP Linkages for Uranium

\section{A.3 Hanford Site: 100 Area Research Integration Example}

Hexavalent chromium. Cr(VI) contamination in groundwater is widespread within the DOE complex, including in the subsurface at Hanford, INL, SRS, Pantex Plant, ORR, and Lawrence Livermore National Laboratory sites. The total volume of DOE Cr(VI)-contaminated groundwater is estimated to be $4.9 \times$ $10^{10} \mathrm{~L}$, and the maximum mass of $\mathrm{Cr}(\mathrm{VI})$ is estimated to be $2.8 \times 10^{5} \mathrm{~kg}$ (Hazen et al. 2009).

A significant volume of $\mathrm{Cr}$ (VI) contamination exists at the Hanford 100-D/H Areas (Figure A.4). Although specific release points of chromium into the subsurface remain largely unknown, the source of $\mathrm{Cr}(\mathrm{VI})$ contamination is sodium dichromate used for corrosion control at Hanford's old plutonium reactor systems and for decontaminating the shut-down reactor complexes. The 100-D Area aquifer has the highest concentrations of chromium at Hanford (>10,000 ppb) (DOE-RL 2008a). Cr(VI) concentrations in groundwater samples near the Columbia River shore are at levels greater than $200 \mathrm{ppb}$ in a few locations, which is more than 10 times the remedial action objective of $20 \mathrm{ppb}$ for groundwater discharge into the river (DOE-RL 2008a). 


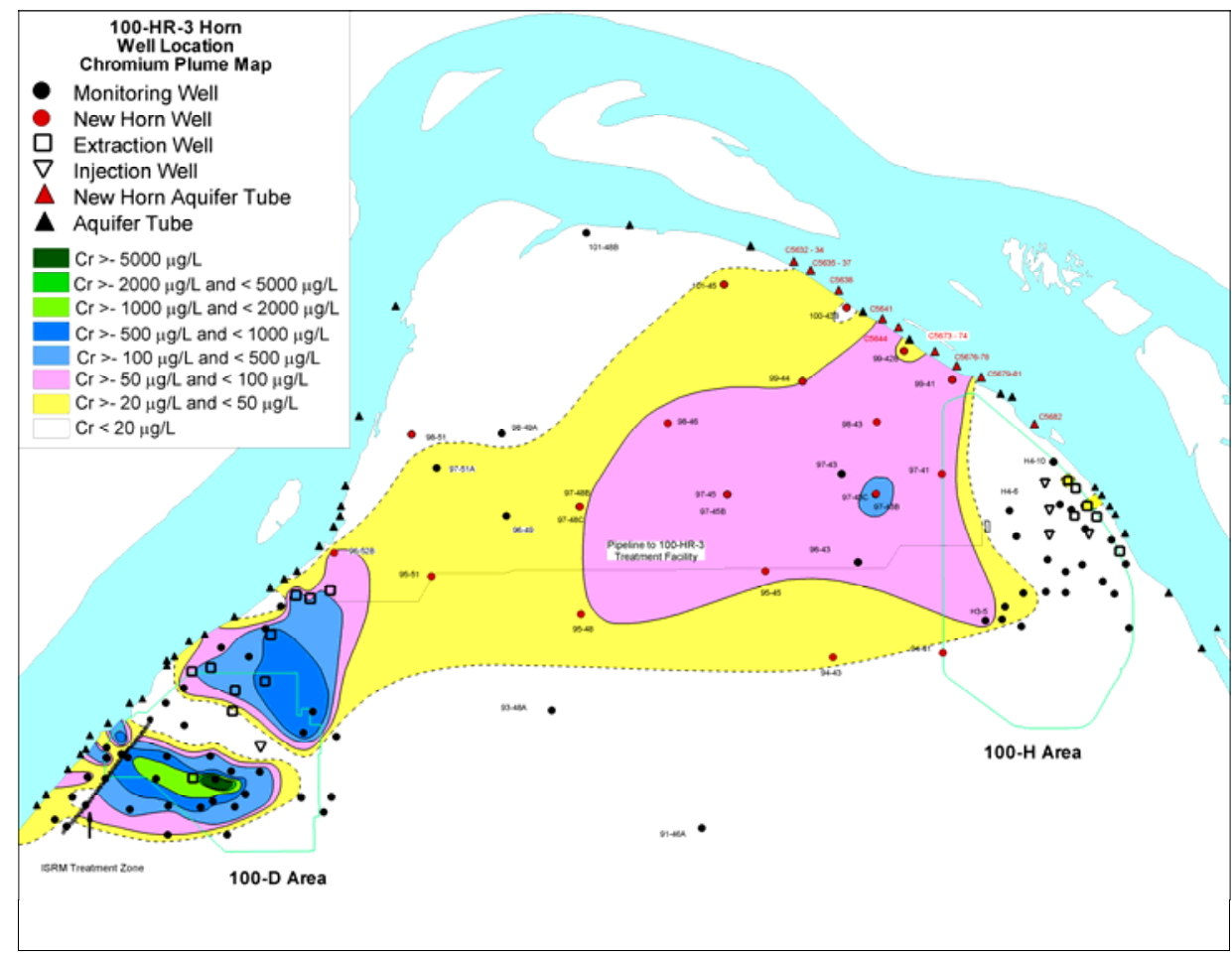

Figure A.4. Map of Cr Concentration in Groundwater at Hanford 100-H and 100-D Areas, Both Located Near the Columbia River

Newly proposed remedial action objectives for the Hanford 100 Area include 1) reducing Cr(VI) groundwater discharge into the river to $20 \mu \mathrm{g} / \mathrm{L}$ by 2012;2) remediating all other groundwater $\mathrm{Cr}(\mathrm{VI})$ to $\leq 48 \mu \mathrm{g} / \mathrm{L}$ by 2020 , and 3 ) reducing soil $\mathrm{Cr}(\mathrm{VI})$ concentrations to prevent future groundwater contamination. To meet these objectives, various remediation methods have been implemented and others are now being planned. Previous remedial actions include excavation of surface contamination sites (Poston et al. 2008) and two pump-and-treat systems for the groundwater (Piepho et al. 2008). In addition, an In Situ Redox Manipulation (ISRM) barrier was installed as a permeable treatment barrier to prevent $\mathrm{Cr}(\mathrm{VI})$ from the highest concentration plume in the 100-D Area from entering the river (DOE-RL 2008a). Through a remedial process optimization effort, the site has identified expansion and enhancement of the existing pump and treat systems and source area (both vadose and saturated zone) and bioremediation as the methods best suited to meet their remedial action objectives.

Significant basic and applied research has been conducted by SC ERSP, EM-22, and site-funded scientists; this research has led to the development of an excellent foundation for considering upcoming remedial action objectives. At the 100-H Area, a joint EM-SC funded project was initiated in 2002 to explore the potential for $\mathrm{Cr}$ immobilization via biostimulation with a slow release polylactate. This project has continued since 2005 with SC funding and has been successful in illustrating how biostimulation could decrease the $\mathrm{Cr}(\mathrm{VI})$ concentrations to below drinking-water MCL in the vicinity of the injection well for $\sim 3$ years (Faybishenko et al. 2008) and how geophysical methods can be used to remotely monitor the spatiotemporal distribution of the injected electron donor and remediation endproducts (Hubbard et al. 2008). A 2005 review of the 100-D Area Cr(VI) plume and ISRM barrier performance recommended a number of actions to enhance treatment of the $\mathrm{Cr}(\mathrm{VI})$ plume and enhance the longevity and performance of the ISRM barrier, one of which was to conduct bioremediation 
upgradient of the ISRM barrier to decrease dissolved oxygen, nitrate, and $\mathrm{Cr}$ (VI) concentrations flowing into the barrier. Subsequently, EM-funded scientists have been conducting a treatability test to explore commercially available approaches using molasses and vegetable oil to create a large-scale biological reducing barrier for the 100-D Area (Truex et al. 2007, 2008). At the molasses test site, substrate injection reached the target radius and reducing conditions have been maintained for over 15 months. Emulsified vegetable oil was injected later at another test site and reached the target radius. Reducing conditions have been maintained through the first 4 months of monitoring at this site. Continued monitoring is planned at both sites.

Although the experiments described above indicate that $\mathrm{Cr}(\mathrm{VI})$ reduction via biostimulation is feasible, questions regarding the mechanisms at play and the sustainability of the approach are unresolved in the saturated zone and are untested in the vadose zone. For example, the dominant biogeochemical reaction pathway that governs sustained $\mathrm{Cr}(\mathrm{VI})$ reduction in the saturated zone is unknown (biotic, abiotic, combination of both?). Similarly, the control of Mn oxides on reoxidation and the potential for "recycling" carbon within the aquifer via metabolic activity is unknown; these three questions form the basis of the current ERSP-supported efforts at the Hanford 100-H Site. A significant opportunity exists to build on the excellent hydrogeological and biogeochemical foundation that has been developed by the participating research groups through a coordinated program of basic and applied research. The development of a coordinated and unified EM and ERSP effort has significant potential to positively impact the use of bioremediation as a component of the 100 Areas Record of Decision. In addition, the information should provide relevant insights and tools that are transferable for other locations within the DOE complex where Cr(VI) is a key contaminant of concern. Figure A.5 describes the integration and collaboration between EM and ERSP activities at the Hanford Site 100 Area. 


\section{HANFORD 100 AREA EM AND ERSP LINKAGES}

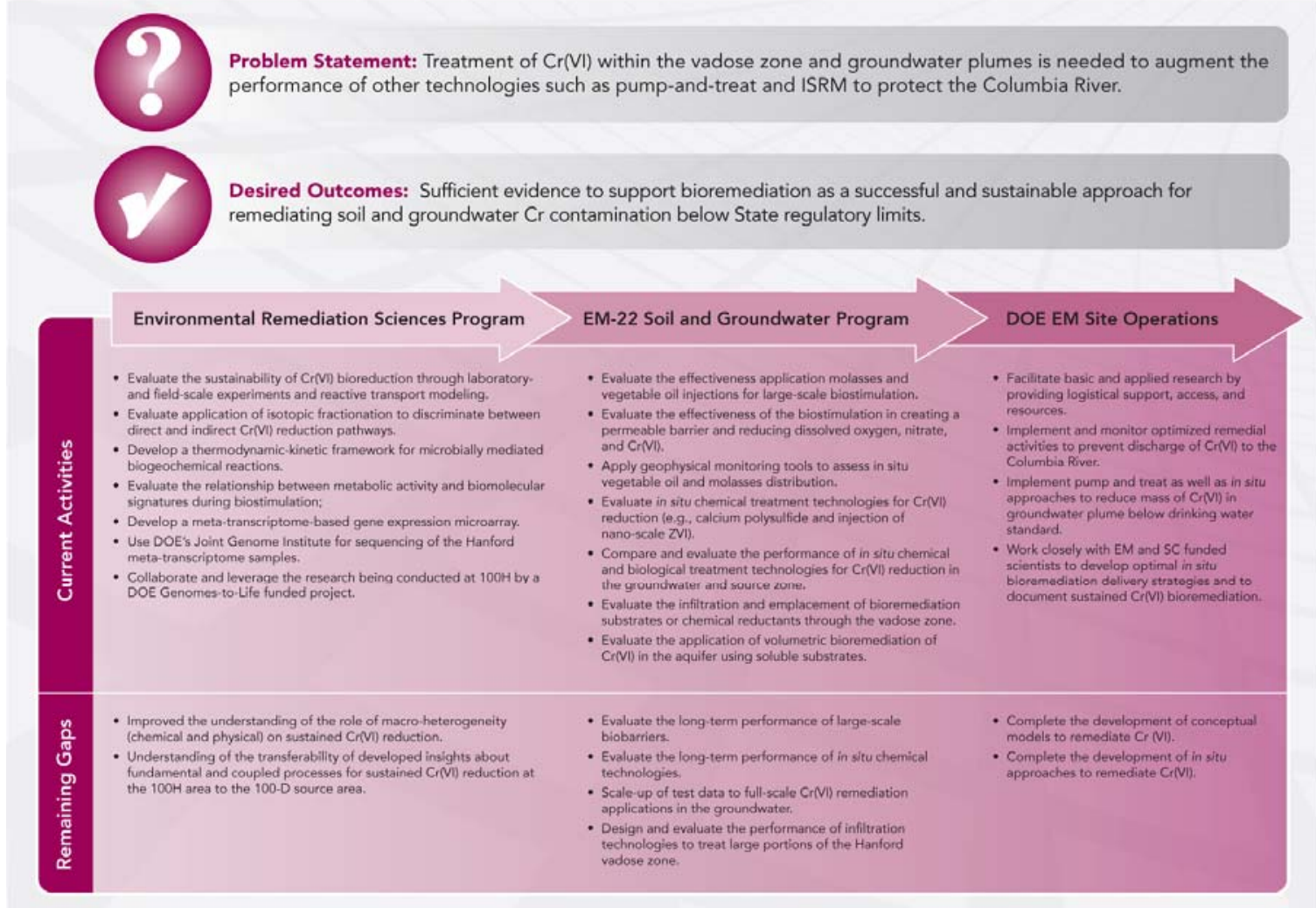

Figure A.5. Hanford 100 Area EM and ERSP Linkages

\section{A.4 Hanford Site: 300 Area Research Integration Example}

The 300 Area in the southern portion of the Hanford Site was used for research and fabrication of uranium into fuel rods for nuclear reactors in the northern portion of the Hanford Site. Wastes were discharged to the ground in large waste ponds, trenches, and cribs (Peterson et al. 2008). The greatest impact to groundwater from disposal of waste containing uranium probably occurred during the period of Hanford's peak plutonium production, i.e., the 1950s through the mid-1960s. During this period, effluent was directed to a pair of process ponds and a lesser amount to nearby process trenches. All of these facilities are within the Columbia River Corridor because they are located adjacent to the river shoreline. Contaminated process wastes continued to be discharged during the 1970s and 1980s, with disposal shifting to the 300 Area process trenches in the mid-1970s. The 300 Area was further contaminated because of leakage from the process sewer system, which delivered fuel fabrication and other process and research waste effluents to the various disposal sites (Lindberg and Bond 1979). These discharges included uranium in concentrations that resulted in an extensive groundwater plume that occupies a significant portion of the 300 Area. In 1996, an interim record of decision was reached that included excavating contaminated sediments beneath the waste pond footprints, backfilling with nearby materials, and revegetating the surface. The plume was projected to attenuate in 10 years, and monitoring was 
selected as the interim remedy for the uranium-contaminated groundwater. The interim remedy has not met the objectives, and uranium concentrations in groundwater have remained above the regulatory limit.

A limited field investigation (LFI) has been completed as part of a remedial investigation/feasibility study. The LFI and associated scientific investigations conducted by DOE EM and CESD determined that low concentrations of uranium remaining in the vadose zone and "smear zone" at the interface with the unconfined aquifer are sufficient to cause the persistent groundwater concentrations. The LFI results were used, along with the results of other investigations conducted outside the CERCLA program, to refine the conceptual site model for uranium in the 300 Area. The conceptual model is used to guide the remedial investigation and feasibility study and arrive at a final remedy for the uranium contamination in the 300 Area.

The DOE EM-22 Groundwater and Soil Remediation Program invested in a potential remediation approach for the uranium-contaminated groundwater in the 300 Area. To evaluate the feasibility to remediate the uranium contamination in situ, the EM-22 polyphosphate treatability test included laboratory and field-scale investigations in the 300 Area. The concept of using polyphosphate as a remediation technology began as an EMSP proposal (a joint DOE EM and SC administered research program) that was funded in the 1999 proposal solicitation. The laboratory investigations were used to characterize the processes controlling the precipitation of the minerals autunite and apatite from polymeric phosphate species, including interactions and precipitation kinetics, dissolution kinetics of uranium source minerals, and interactions with uranium minerals. To prepare for field-scale treatability testing, geochemical and hydrodynamic characterization was completed at field sites. The polyphosphate technology was injected into the 300 Area near the North Process Pond at the southern end of the 300 Area process trenches (316-5) into a source or "hot spot" area. The intent of the test was to reduce the inventory of available uranium that contributes to the groundwater plume through direct precipitation of uranyl-phosphate solids and secondary containment via precipitation of apatite acting as a long-term sorbent for uranium. The objective of the treatability test was to evaluate the efficacy of using polyphosphate injections to treat uranium-contaminated groundwater in situ. The test site consisted of an injection well and 15 monitoring wells. Results indicated the sequestration of uranium as insoluble phosphate phases worked for treating the uranium-contaminated groundwater; however, the formation of the apatite during the test was more limited. A different approach for remediation of the 300 Area uranium contamination was determined to be reduction of the contamination source, primarily the smear zone in the capillary fringe above the unconfined aquifer, via the polyphosphate technology. The current approach for the 300 Area is to evaluate field-scale infiltration of the polyphosphate technology to treat the smear zone. The Hanford Site Remediation contractor, CH2M Hill Plateau Remediation Contractor (CHPRC), funded by DOE Richland Operations, is performing laboratory studies and field characterization to prepare for the field-scale infiltration test. The field-scale infiltration test will be conducted near the southern end of the North Process Pond.

CESD has investigated a number of aspects of uranium behavior in the 300 Area. Zachara et al. (2007) and McKinley et al. (2007) summarized research that has been performed on both saturated zone and unsaturated zone sediments. When the North and South Process Pond excavations were open, four test pits were dug to collect sediment samples to the water table. These samples provided the basis for the updated uranium conceptual model documented in the remedial investigation report and for the optimization of the polyphosphate technology for treating the smear-zone contamination source in laboratory- and intermediate-scale experiments. Research is continuing in the 300 Area, funded both 
through the PNNL SFA and at an IFRC site within the footprint of the South Process Pond. The CESD, through the SFA and IFRC, is performing 1) studies of the geochemical identity and physical location of precipitated and adsorbed uranium species, 2) laboratory evaluations of the in situ adsorption-desorption behavior of uranium, 3) experimental evaluations for upscaling laboratory-based parameters to the field, and 4) coupled process interactions controlling uranium fluxes from the vadose zone to groundwater and between groundwater zones of different permeability. The SFA is investigating the geochemical identity and physical location of precipitated and sorbed uranium species and studying the mechanistic, speciation-based kinetic uranium release from contaminated capillary fringe and aquifer sediments. The SFA is also performing microbial characterization in the 300 Area unconfined aquifer by conducting a census of microbial populations (distribution, function, and activity) and determining the biogeochemical processes that impact long-term uranium behavior. The IFRC is measuring and modeling mass transfer and its effects on uranium concentrations at various scales and developing an integrated threedimensional geostatistical model of flow and geochemical reaction parameters for the experimental domain of the project. The goal of all this research is to elucidate field-scale mass-transfer processes for uranium and provide new knowledge and models to influence effective and defensible remediation decisions, particularly for the 300 Area uranium plume.

DOE EM is continuing to interface with the 300 Area IFRC and PNNL SFA projects. The resulting updated scientific findings and conceptual model will be used by DOE EM to assist in selecting a final remediation approach by 2015. Figure A.6 describes the integration and collaboration between EM and ERSP activities at the Hanford Site 300 Area.

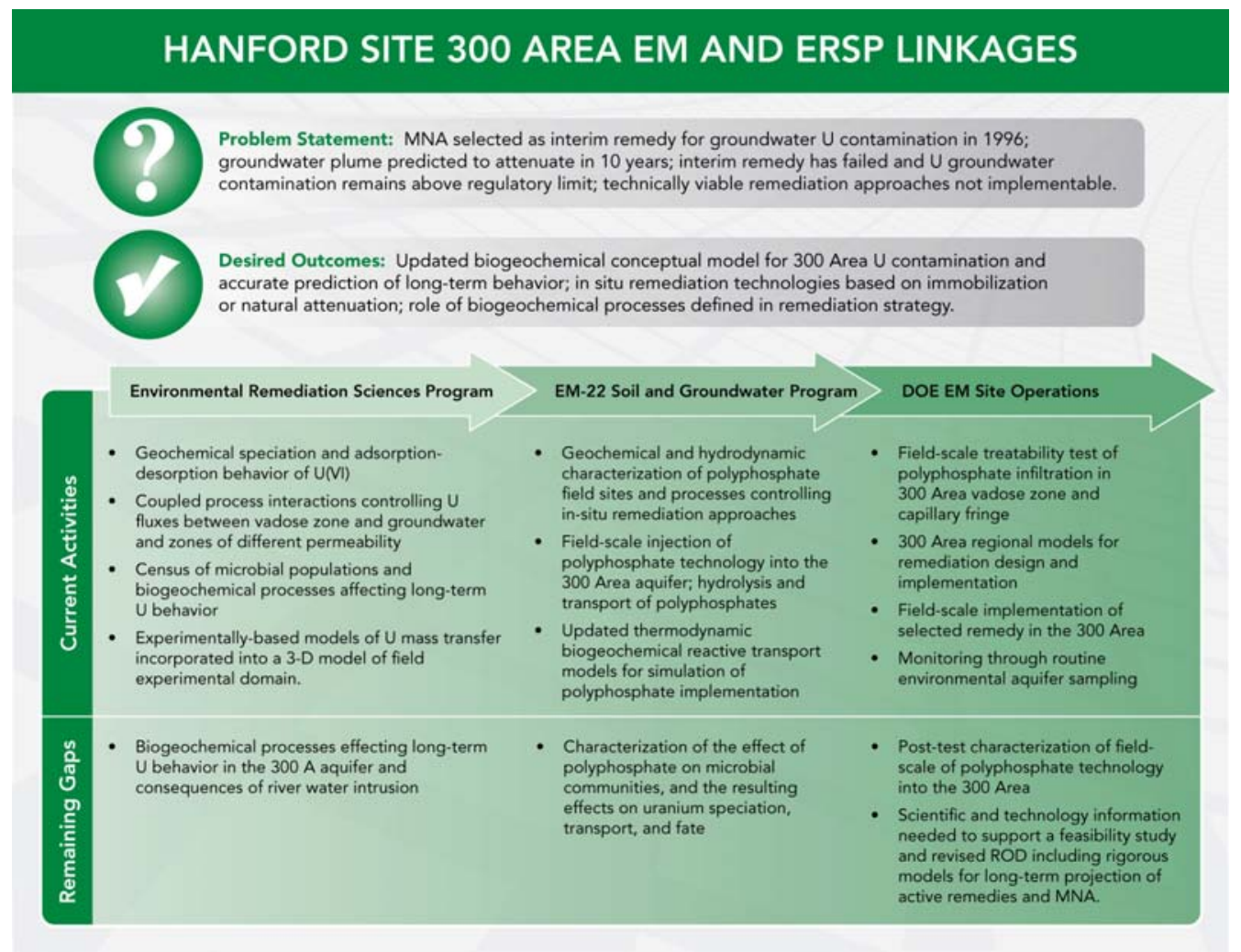

Figure A.6. Hanford 300 Area EM and CESD Linkages 


\section{A.5 Hanford Site: BC Cribs and Trenches Research Integration Example}

Tank wastes were reprocessed to recover uranium at the Hanford Site. When this was done during the 1950s, wastes were directly disposed of to the soil, put back into a tank, or returned to a series of tanks, allowing most of the solids to settle. The remaining supernatant, which was highly concentrated radioactive and hazardous waste, was discharged to the soil. The $\mathrm{BC}$ cribs and trenches received in excess of 189-million liters (50-million gallons) of this so-called scavenged tank waste. Based on inventory estimates, this group of sites contains the largest inventory of ${ }^{99} \mathrm{Tc}$ disposed of to the soil on the Hanford Site. Groundwater monitoring data for the BC cribs and trenches is limited, but little of the inventory from these sites appears to have reached the water table. Release of ${ }^{99} \mathrm{Tc}$ from these waste sites is projected to lead to future groundwater contamination above the MCL.

Technetium-99 associated with the BC cribs and trenches inventory resides deep within the vadose zone of the central plateau, and remediation of this contamination is not feasible with existing technologies. Therefore, the remediation contractor at the Hanford Site, currently CHPRC is conducting a deep vadose zone treatability test (DOE-RL 2008b). The goal of the field test is to evaluate vadose zone remediation technologies and includes a comprehensive set of laboratory, modeling, and field tests. While the test is being conducted at the $\mathrm{BC}$ cribs and trenches, characterizing and remediating the site are not goals of the testing program. The field test will result in technical performance data for soil desiccation and other technologies, thereby providing the technical basis for comparing and evaluating the technologies as part of subsequent remedial alternative assessments.

DOE Richland Operations and the remediation contractor have performed geochemical and hydrodynamic characterization of the field site. The characterization included installing boreholes through several of the trenches, sediment sampling, and analysis. The analysis results (Serne and Mann 2004) showed that there was ${ }^{99} \mathrm{Tc}$ at depth in the vadose zone beneath the trench, although the areal extent was not known. Subsequent modeling by Ward et al. (2004) predicted that the contamination had spread laterally, which was investigated by high-resolution electrical resistivity geophysical surveys (Rucker and Benecke 2006). A draft document exists that describes an effort to ground truth the resistivity survey by installing boreholes and sampling and analyzing sediments. DOE Richland Operations and the remediation contractor will be responsible for implementing the final remedy for remediating deep vadose zone ${ }^{99} \mathrm{Tc}$ and $\mathrm{U}$.

EM-20 is supporting the $\mathrm{BC}$ cribs and trenches through activities on the Enhanced Remediation of Metals and Radionuclides Initiative. The initiative is investigating methods to control, reduce, and/or remove metals and radionuclides (e.g., $\mathrm{Cr}, \mathrm{Pu}, \mathrm{Sr}, \mathrm{Tc}$, and $\mathrm{U}$ ) from the vadose zone. This collaborative effort includes teams from PNNL, INL, MSE Technology Applications, Inc., and private industry collectively working together to address various aspects of the initiative. Recently, the initiative conducted a literature review documenting the state of knowledge for ${ }^{99} \mathrm{Tc}$, its behavior in the environment, and possible remediation approaches (Icenhower et al. 2008). The feasibility of foam-based delivery of amendments is being evaluated by the project, along with support from the EM OE\&T Advanced Fate and Transport Models Initiative, which is developing simulation capabilities to support foam delivery of reagents. The modeling initiative is also extending the model of $\mathrm{BC}$ cribs and trenches to evaluate uncertainties associated with soil desiccation, including the effects of heterogeneities. 
DOE SC, through the PNNL SFA, is investigating the redox chemistry of ${ }^{99} \mathrm{Tc}$ in Hanford sediments and evaluating the biogeochemistry of microbial isolates toward ${ }^{99} \mathrm{Tc}$ and $\mathrm{U}$ in different Hanford facies. These investigations will result in improved predictions of transport behavior for both ${ }^{99} \mathrm{Tc}$ and $\mathrm{U}$ that can be used to remediate the deep vadose zone contamination through in situ, enhanced attenuation, or monitored natural attenuation methods.

The technical gaps for $\mathrm{BC}$ cribs and trenches include field-scale remediation approaches based on scientific studies. A strategy is needed to evaluate specific remediation technologies for deep vadose zone ${ }^{99} \mathrm{Tc}$ and U. Scientific and technology information are needed to provide the technical basis for decisions regarding deep vadose zone remediation across the Central Plateau. Figure A.7 describes the integration and collaboration between EM and ERSP activities at the Hanford Site BC Cribs and Trenches.

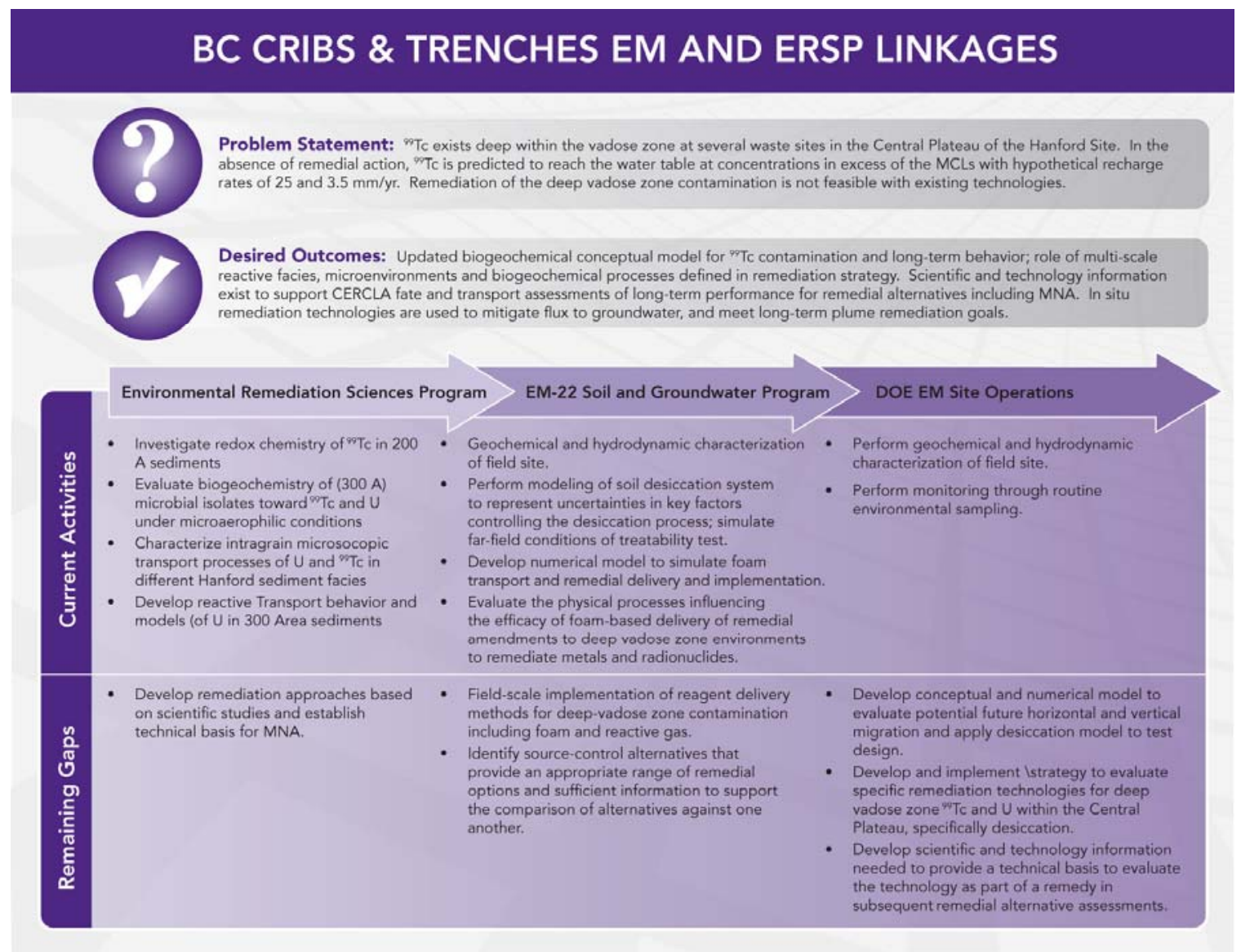

Figure A.7. Hanford BC Cribs and Trenches EM and CESD Linkages 


\section{A.6 References}

\section{DOE (see U.S. Department of Energy)}

Faybishenko B, TC Hazen PE Long, EL Brodie, ME Conrad, SS Hubbard, JN Christensen, D Joyner, SE Borglin, R Chakraborty, KH Williams, JE Peterson, J Chen, ST Brown, TK Tokunaga, J Wan, M Firestone, DR Newcomer, CT Resch, KJ Cantrell, A Willett, and S Koenigsberg. 2008. "In Situ Long-Term Reductive Bioimmobilization of Cr(VI) in Groundwater Using Hydrogen Release Compound.” Environmental Science \& Technology 42(22):8478-8485.

Fenimore JW, and JH Horton. 1972. Rating history and environmental effects of seepage basins in the chemical separations areas of the Savannah River Plant. DPST-72-548; USAEC: Washington, D.C.

Hazen TC, B Faybishenko, and P Jordan. 2009. “Complexity of groundwater contaminants at DOE sites." Environmental Science and Technology, In Review.

Hubbard SS, K Williams, M Conrad, B Faybishenko, J Peterson, J Chen, P Long, and T Hazen. 2008. "Geophysical monitoring of hydrological and biogeochemical transformations associated with $\mathrm{Cr}(\mathrm{VI})$ Biostimulation.” Environmental Science and Technology 42(10):3757-3765.

Icenhower JP, NP Qafoku, WJ Martin, and JM Zachara. 2008. The Geochemistry of Technetium: A Summary of the Behavior of an Artificial Element in the Natural Environment. PNNL-18139, Pacific Northwest National Laboratory: Richland, Washington.

Killian TH, NY Kolb, P Corbo, and IW Marine. 1987. F-Area Seepage Basins. DPST-85-706; Savannah River Laboratory, Aiken, South Carolina.

Lindberg JW, and FW Bond. 1979. Geohydrology and Groundwater Quality Beneath the 300 Area, Hanford Site, Washington. PNL-2949; Pacific Northwest Laboratory: Richland, Washington.

McKinley JP, JM Zachara, J Wan, DE McCready, and SM Heald. 2007. "Geochemical Controls on Contaminant Uranium in Vadose Zone Hanford Formation Sediments at the 200 Area and 300 Area, Hanford Site, Washington." Vadose Zone Journal 6:1004-1017.

Peterson RE, ML Rockhold, RJ Serne, PD Thorne, and MD Williams. 2008. Uranium Contamination in the Subsurface Beneath the 300 Area, Hanford Site, Washington. PNNL-17034; Pacific Northwest National Laboratory: Richland, Washington.

Piepho MG, JL Smoot, HS Anastos, RS Edrington, MJ Hartman, GG Kelty, and RF Raidl. 2008. Calendar Year 2007 Annual Summary Report for 100-HR-3, 100-KR-4, and 100-NR-2 Operable Unit OU Pump and Treat Operation. DOE/RL-2008-05, Rev. 0, U.S. Department of Energy, Richland, Washington.

Poston TM, JP Duncan, and RL Dirkes. 2008. Hanford Site Environmental Report for Calendar Year 2007. PNNL-17603; Pacific Northwest National Laboratory: Richland, Washington. 
Serne RJ, and FM Mann. 2004. Preliminary Data from 216-B-26 Borehole in BC Cribs Area. RPP-20303, Rev. 0, CH2MHill Hanford Group: Richland, Washington.

Truex MJ, VR Vermeul, PE Long, FJ Brockman, M Oostrom, S Hubbard, RC Borden, JS Fruchter. 2007. Treatability Test Plan for an In Situ Biostimulation Reducing Barrier. PNNL-16424, Pacific Northwest National Laboratory, Richland, WA.

Truex MJ, VR Vermeul, RD Mackley, BG Fritz, DP Mendoza, CD Johnson, RP Elmore, FJ Brockman, CL Bilskis. 2008. Hanford 100-D Area Biostimulation Soluble Substrate Field Test: Interim Data Summary for the Substrate Injection and Process Monitoring Phases of the Field Test. PNNL-17619, Pacific Northwest National Laboratory, Richland, WA.

U.S. Department of Energy (DOE). 1997. Linking Legacies: Connecting the Cold War Nuclear Weapons Processes to Their Environmental Consequences. DOE/EM-0319; U.S. DOE Office of Environmental Management: Washington, D.C.

U.S. Department of Energy (DOE). 2006. Environmental Remediation Sciences Program Strategic Plan: Solving the DOE's intractable problems in environmental remediation and stewardship. DOEOffice of Biological and Environmental Research, Environmental Remediation Sciences Division: Washington, D.C.

U.S. Department of Energy (DOE-RL). 2008a. In Situ Redox Manipulation (ISRM) Annual Report Fiscal Year 2007. DOE/RL-2008-10, Rev. 0, U.S. Department of Energy: Richland, Washington.

U.S. Department of Energy-Richland Operations (DOE-RL). 2008b. Deep Vadose Zone Treatability Test Plan for the Hanford Central Plateau. DOE/RL-2007-56, Rev. 0, Richland, Washington.

Ward AL, GW Gee, ZF Zhang, and JM Keller. 2004. Vadose Zone Contaminant Fate and Transport Analysis for 216-B-26 Trench. PNNL-14907; Pacific Northwest National Laboratory: Richland, Washington.

Zachara JM, CF Brown, J Christensen, PE Dresel, S Kelly, JP McKinley, RJ Serne, and W Um. 2007. A Site-wide Perspective on Uranium Geochemistry at the Hanford Site. PNNL-17031; Pacific Northwest National Laboratory: Richland, Washington. 


\section{Distribution}

No. of

Copies

$\underline{\text { OFFSITE }}$

16 U.S. Department of Energy - EM HQ 19901 Germantown Road

Groundwater \& Soil Remediation, EM-22

Cloverleaf Building

Germantown, MD 20874

Attn: V. Adams

P. Beam

G. (Skip) Chamberlain (2)

A. Das

E. Edge (2)

M. Gilbertson

D. Gupta

C. Magnuson

J. Marble

B. Rowley

K. Skubal (2)

J. Wengle

M. Zhu

5 U.S. Department of Energy-SC HQ

19901 Germantown Road

Biological \& Environmental Research, SC-23

Germantown Building

Germantown, MD 20874

Attn: R. Todd Anderson

P. Bayer

J. Michael Kuperburg

D. Lesmes (2)

5 Savannah River National Laboratory

P.O. Box 616

Aiken, SC 29802

Attn: R. Alyward

D. Kaplan

M. Denham (2)

B.B. Looney (2)

K. Vangelas
No. of

Copies

\section{$\underline{\text { OFFSITE }}$}

2 Lawrence Berkeley National Laboratories Earth Sciences Division

1Cyclotron Rd, MS 90-11161

Berkeley, CA 94720

Attn: S.S. Hubbard (2)

3 Oak Ridge National Laboratory

Environmental Sciences Division

Oak Ridge, TN 37831-6038

Attn: L. Liang (2)

D.B. Watson

ONSITE

8 U.S. Department of Energy

B. L. Foley A6-38

J.P. Hanson A5-11

R.D. Hildebrand A6-38

R.W. Lober H6-60

B.M. Mauss H6-60

J.G. Morse A5-11

K. Mike Thompson A6-38

DOE Public Reading Room (2) H2-53

4 CH2MHill Plateau Remediation Company

J.V. Borghese H8-15

M.N. Jaraysi H8-43

L. Lehman H8-51

S.W. Petersen R3-50

M. Wood H8-51

3 Washington River Protection Services

K. Colosi B1-55

S.J. Eberlein S7-66

F.M. Mann S7-66 
No. of

Copies

OFFSITE

25 Pacific Northwest National Laboratory

T. Brouns

K9-69

C.F. Brown

M.J. Fayer

M. Freshley (2)

J. Fruchter

T. Gilmore

J.P. Icenhower

W. Johnson

K.M. Krupka

P. Long

S. Mattigod

E. M. Pierce (2)

B. Riley

R.J. Serne

M. Triplett

M. Truex

W. Um

V. Vermeul

D.M. Wellman

T. Walton

J. Zachara (2)

Information Release (2)
P7-22

K9-33

K9-33

K6-96

K6-96

K6-81

K6-84

K6-81

K9-33

K3-62

K3-62

K6-81

P7-22

K6-52

K6-96

P7-22

K6-96

K3-62

K9-46

K8-96

K1-06
No. of

Copies

OFFSITE

Distr. 2 



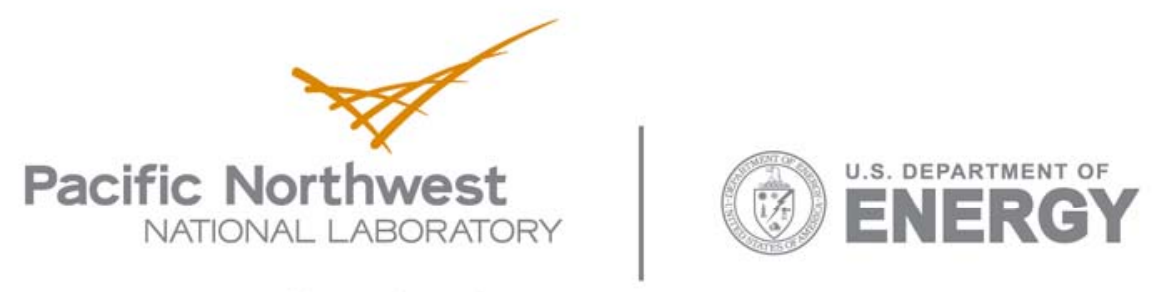

902 Battelle Boulevard

P.O. Box 999

Richland, WA 99352

1-888-375-PNNL (7665)

www.pnl.gov 